\title{
واقع تمكين المرأة السعودية في مؤسسات التعليم العالي
}

\author{
الاكتورة: بتلة صفوق العنزي \\ أستاذ الإدارة التزبوية المساعد لإنائ \\ كلية العلوم و الآداب \\ جامعة الامام - المملكة العربية السعودية
}

ملخص الار اسةة: - مان

هدفت الدراسة إلى الوقوف على و اقع تمكين المر أة السعودية ومشاركتها في بعض القطاعات المختلفة في سوق العمل السعودي وبالتحديد مؤسسات التعليم العالي • و اعتمدت

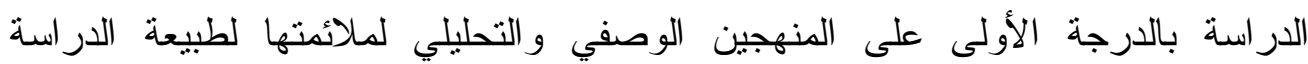

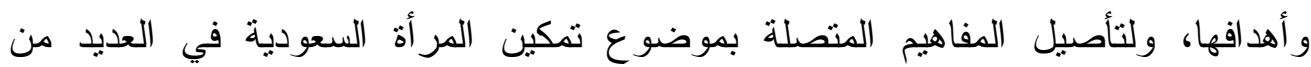

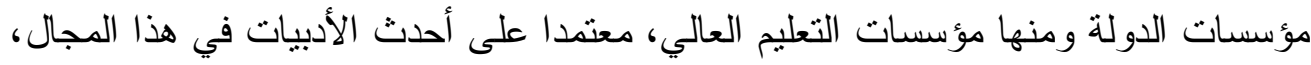
من خلال الإطلاع على الإحصائيات الحكومية والكتب و الدوريات العلمية ذات الاهتمام. وقد تطرقت الدر اسة إلى تحليل بعض القطاعات التي تعمل بها المر أة السعودية، مثل:

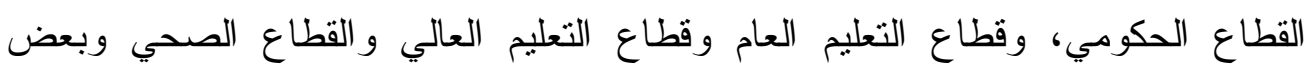

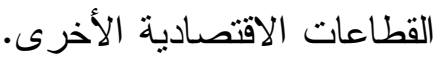

وقد توصلت الدراسة إلى عدة نوصيات ومقترحات من أهمها: إن مشاركة المرأة

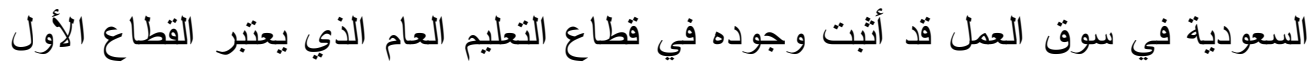

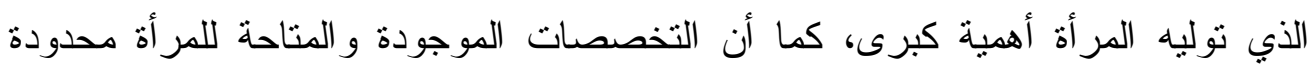

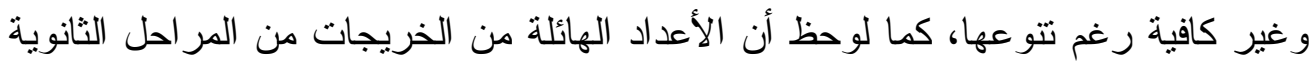
ومعاهد ما بعد الثانوية لا تلتحق بسوق العمل، ويغلب على مخرجات التعليم العالي

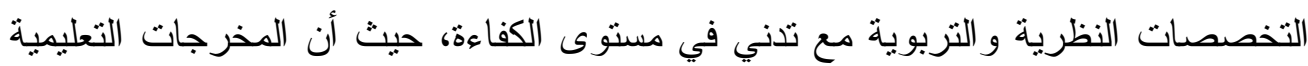

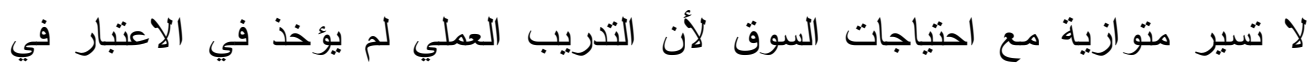
المناهج. وينطبق هذا بصورة متساوية على كل من الرجال و النساء. 


\section{Reality of empowerment of Saudi women in higher education institutions}

Dr.: Batla Safuq Al-Anizi

Assistant professor of educational administration

college of Sciences and Arts

University of Dammam - Saudi Arabia

This study aimed to stand on the empowerment of Saudi women and their participation in some of the different sectors in the Saudi labor market and specifically higher education institutions. The study depended primarily on descriptive and analytical approaches due to the appropriateness to the nature of the study and its objectives, mainstreaming concepts related to the subject of empowerment of Saudi women in various state institutions, including institutions of higher education, depending on recent literature in this area, by reading government statistics, books and journals of interest.

The study dealt with the analysis of some sectors in which they operate Saudi women, such as: the government sector, the sector of public education and higher education sector and the health sector and some other economic sectors.

The study found several recommendations and proposals including: the participation of Saudi women in the labor market has proved itself in the public education sector as it considers of great importance for women, and the disciplines available to women are limited and inadequate, despite their diversity. It was also noted that the huge numbers of graduates from secondary schools and institutes do not join the labor market, predominantly on the output of higher education disciplines, and educational theory with the decline in the level of efficiency, as the learning outcomes do not run parallel with the needs of the market because the practice was not taken into account in the curricula. This applies equally to both men and women. 


\section{مقدمة الار اسة - مقة}

لا شك أن تمكين المرأة من أداء دورها المنشود يمثل عملية محورية في تحقيق أهداف التتمية، فعلى سبيل المثال الحد من الفقر لا يمكن أن يتحقق دون المشاركة الفعالة

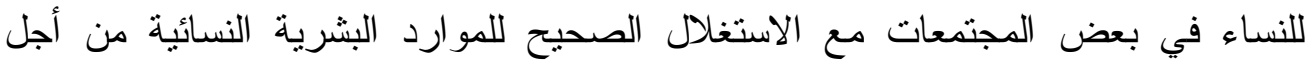

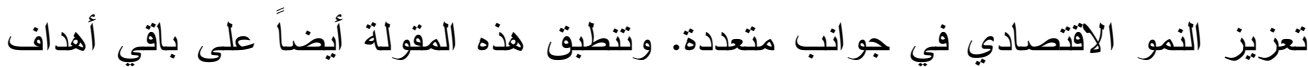

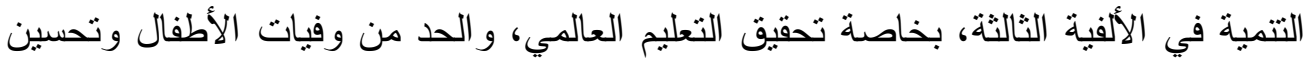

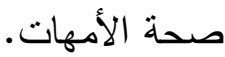

وقد أدرك الباحثون على مدى فترات طويلة أن أهمية تعليم البنات وسيلة لتحسين الصحة في كافة أنحاء المجتمع وتقليل التفرقة بين الجنسين، فكانت النتيجة النهائية لهذا

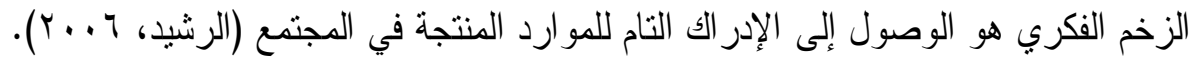
إن موضوع تمكين المرأة أصبح ركناً أساسياً في الحياة العامة لاى كافة المجتمعات

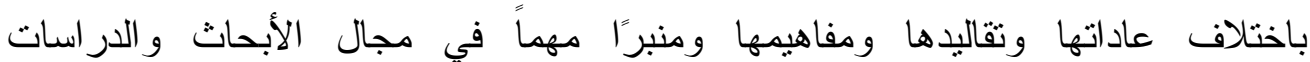
و المؤتمر ات و المحافل الدولية.

ما يخص جذور مفهوم التمكين، فتعود لعقد الستينات من القرن الماضي، فقد ارتبط ظهور هذا المفهوم بالحركة الاجتماعية المنادية بالحقوق المدنية والاجتماعبة للمو اطنين، ومنذ ذلك الحين استخدم مفهوم التمكين بعدة معان، وكذلك استخدم في عدة مجالات منها الاقتصاد و العمل الاجتماعيّ و السياسيّ وكذلك في التتمية. و وامتد مفهوم التمكين كمصطئح

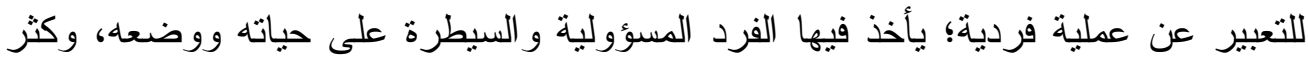

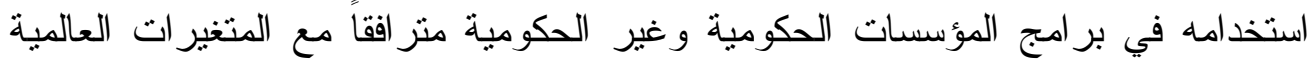

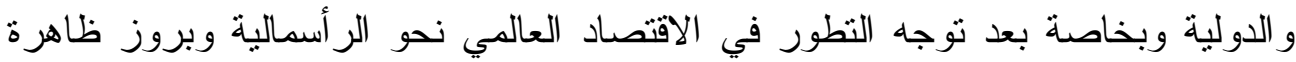
العولمة، وما صاحب ذلك من سياسات إعادة الهيكلة الاقتصادية وما تبعه من آثار سلبية

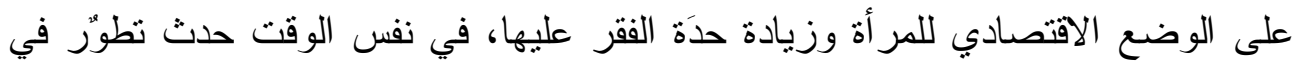

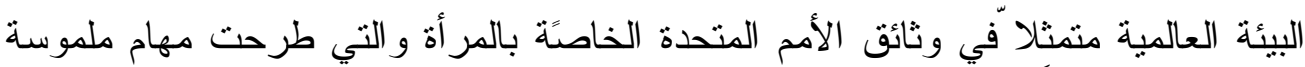

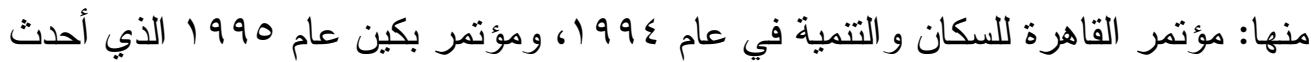

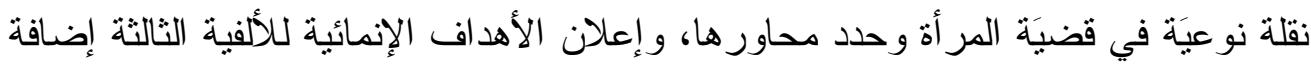



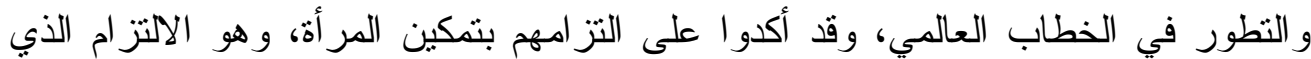
أسهم في وضع أجندة وخطط مؤتمر بكين التي أكدت على تمكين المرأة (قرعان، 7 . . ب). 
إن تمكين المر أة جانب حاسم من جوانب حرية الإنسان. و عند تطبيق مقياس لبيان

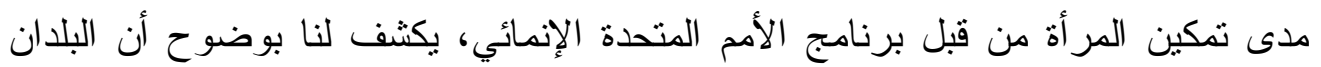

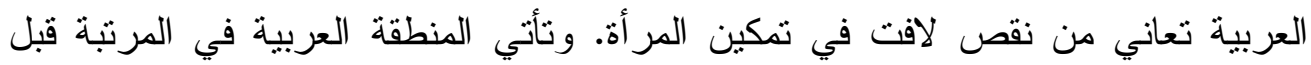

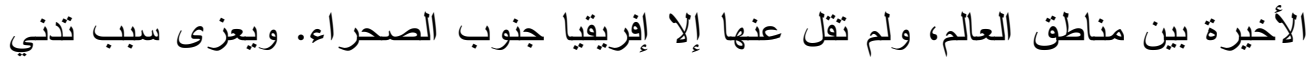

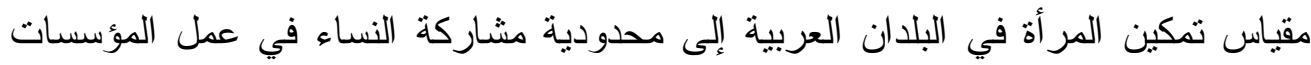

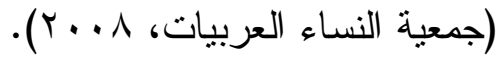

وعلى الرغم من الإنجازات التي حققتها المرأة في مجتمعات دول مجلس التعاون

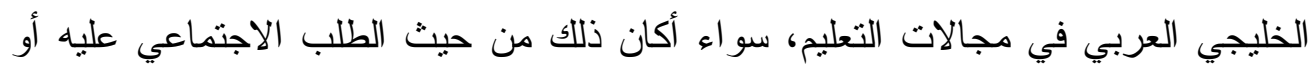

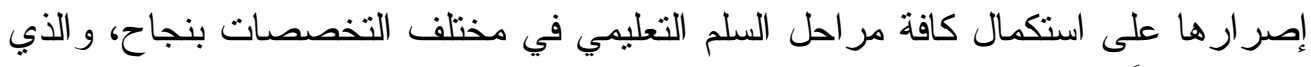

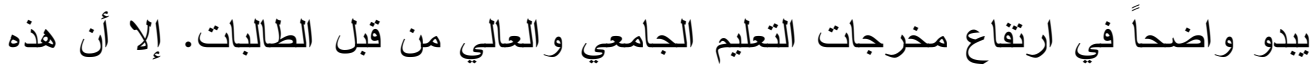

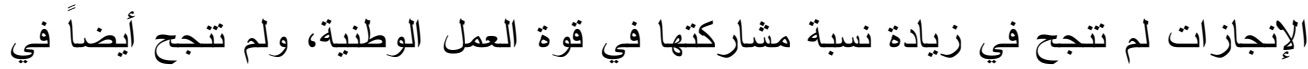

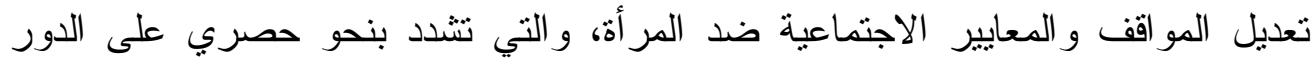

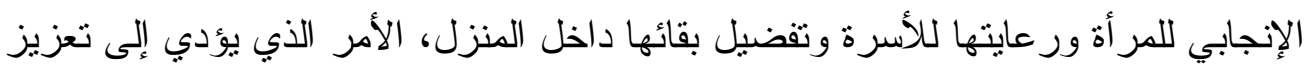

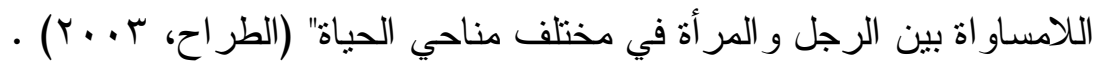

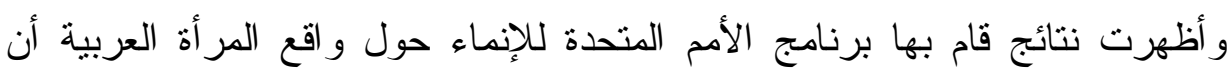

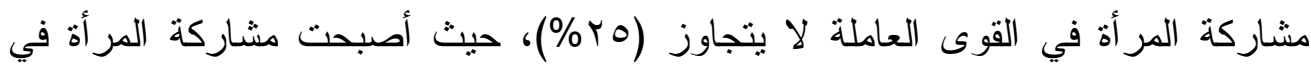

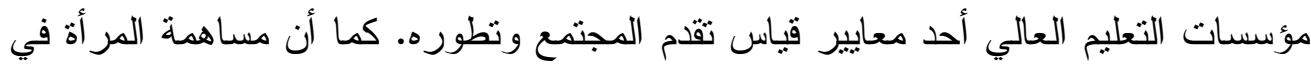

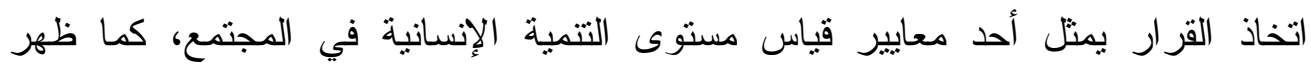

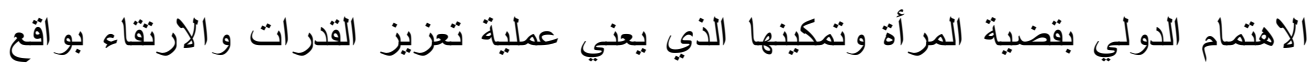

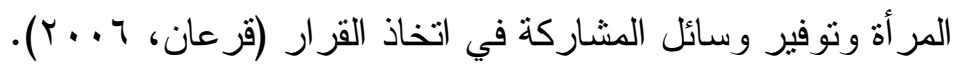

كما تشيرٍ العديدً من الدراسات و الإحصائيات إلى أن تمثيل المرأة في غالبية بلدانٍ العالم ظل دائماً مشوباً بالقصور على مستوى صناعة القرار في جميع القطاعات نقريباً،

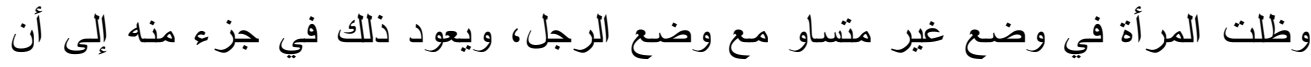

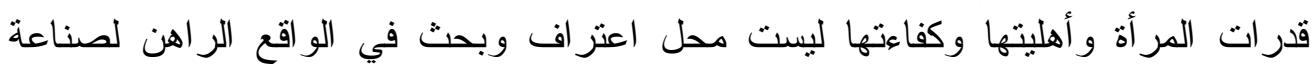

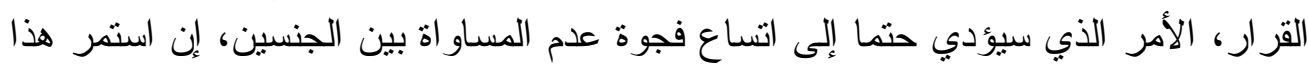

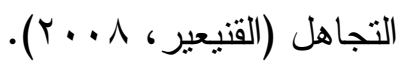

ونظر اً لإدر الك الدور الهام للنساء في رخاء المجتمع ورفاهيته، فقد دعا برنامج الأمم المتحدة الإنمائي بالمملكة العربية السعودية إلى منتدى على مدى ثلاثلة أيام بشأن النساء

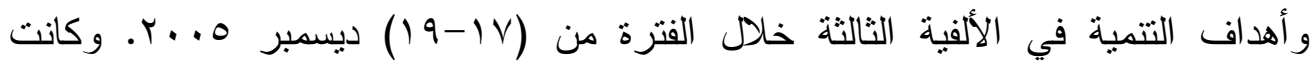


الأهداف الأساسية لهذا المنتدى هي: إلقاء الضوء على دور المر أة في تحقيق أهداف التتمية

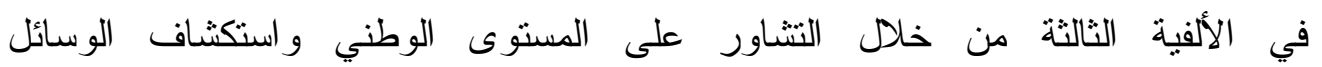

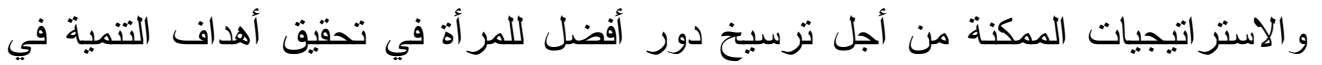

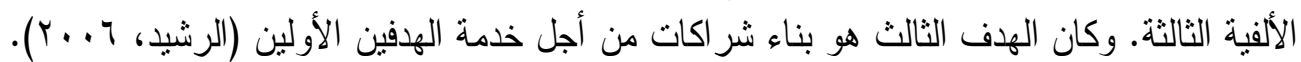

ويلخص التقرير الذي صدر عن هذا المنتدى القضايا الرئيسية، ونوصيات المنتدى، التهن،

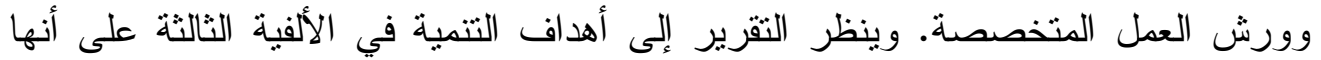

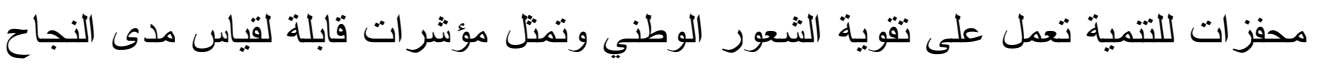

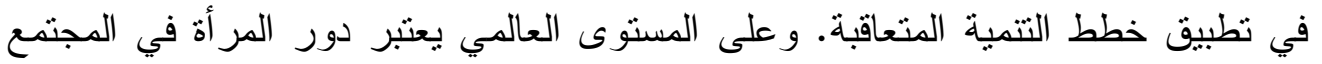

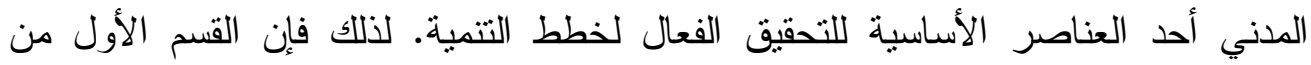

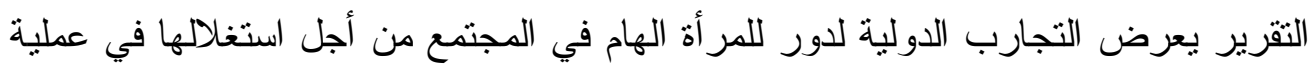

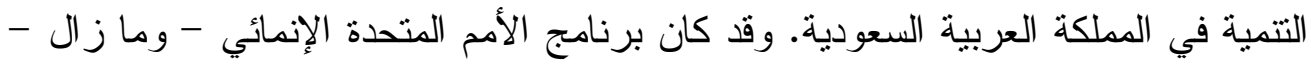

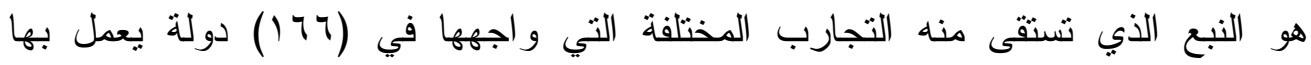

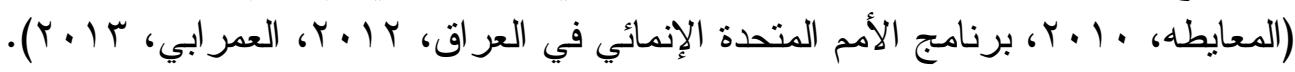
ويلقي القسم الثاني من التقرير الضوء على النواحي الاجتماعية والاقتصادية و الثقافية

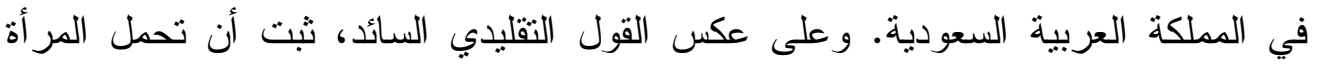

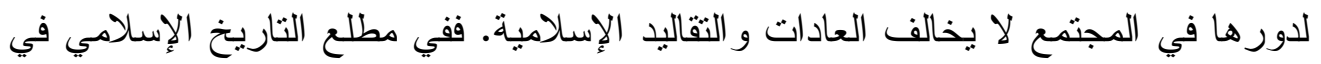

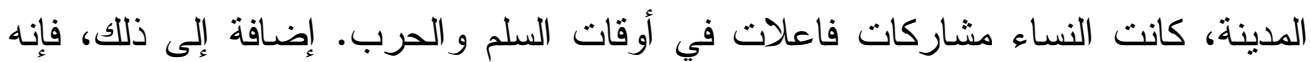

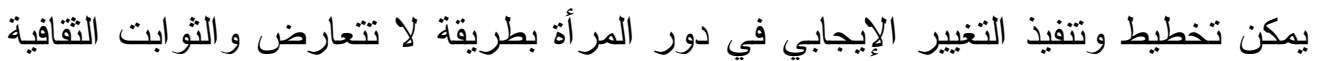

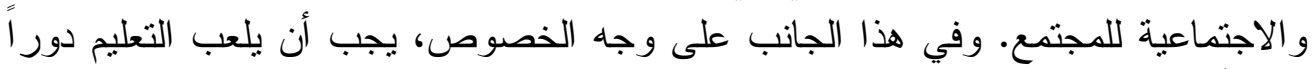

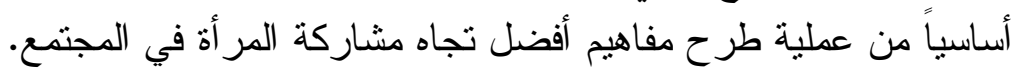
و استتادا إلى هذا المعتقد، فإن القسم الثالث من التقرير يقترح إطار العمليا لمشاركة

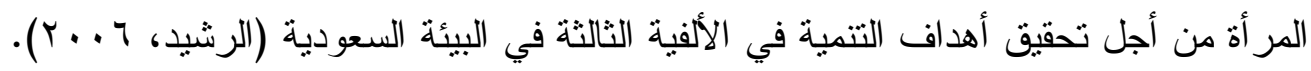
وكان مؤتمر (طوكيو) قد طالب بزيادة معدلات مشاركة المرأة في التعليم العالي

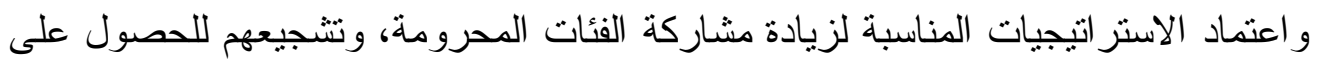

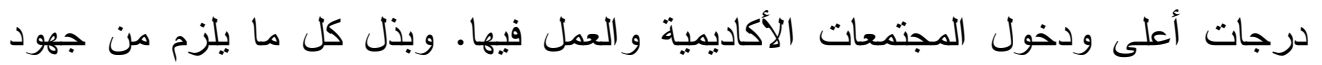
لتشجيع مشاركة الأقليات العرقية)(UNESCO, 1997). كما طالب مؤتمر "داكار" بمشاركة المر أة في جميع المجالات الممكنة في مؤسسات

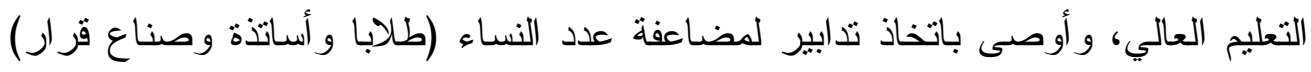

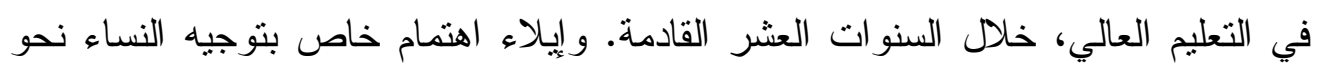

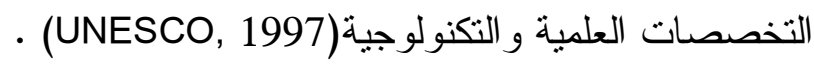


وقامت الحسيني (ب (999) بدر اسة هدفت إلى التعرف على مساهمات المر أة في سوق العمل بعد مرور ربع قرن على تعليم البنات في المملكة العربية السعودية، وتقييم دور

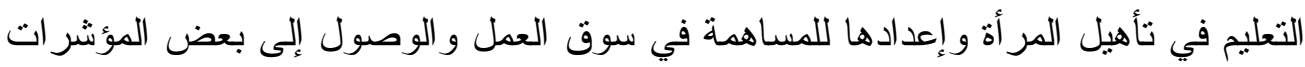

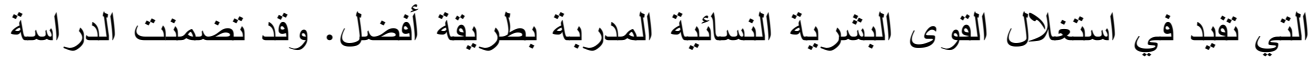



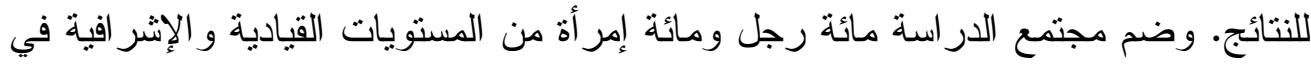

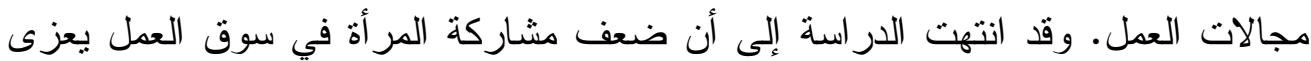

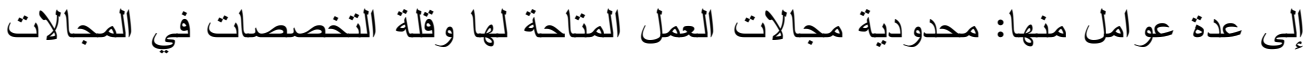

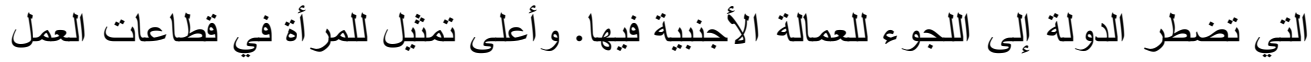

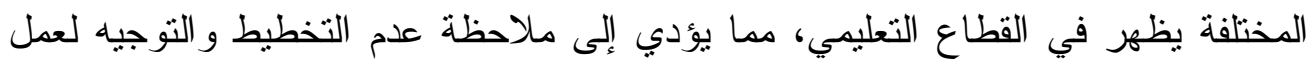

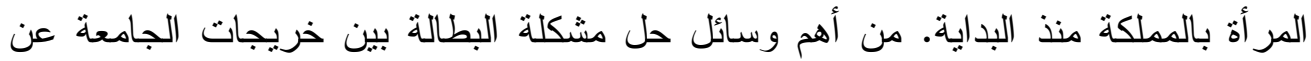

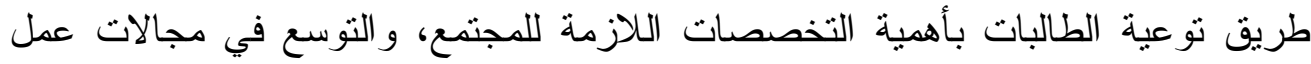
المر أة، و التتسيق بين الجهات التعليمية التي تقوم على تعليم المرأة

و أجرت الثهر اني (997 (197) دراسة بعنوان (مدى إسهام المر أة السعودية المؤهلة في

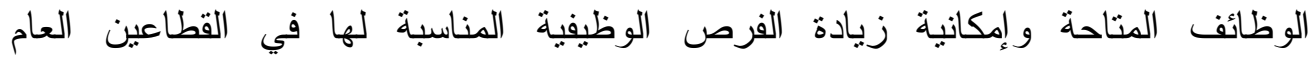
و الخاص). وقد هدفت هذه الدراسة إلى معرفة الفرص الوظيفية المتاحة للمر أة السعودية

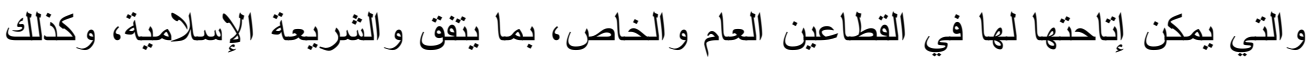

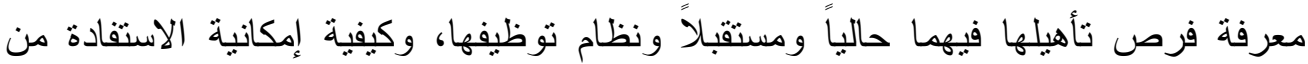

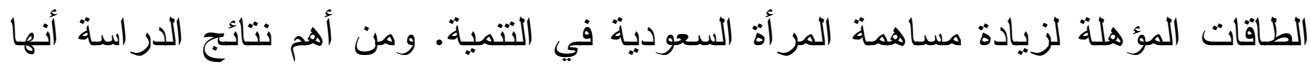

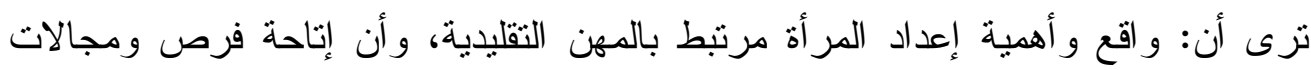

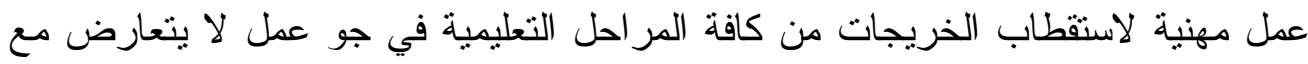

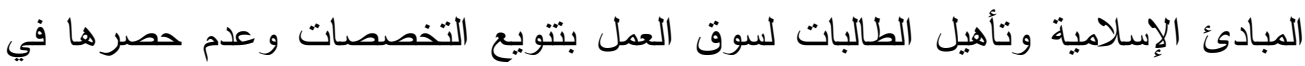
مجال و احد. وقد تضمنت الدراسة عدداً من التوصيات منها أهمية تقييم تجربة مر اكز التهات خدمة المجمع في كافة الجامعات لتدريب الخريجات و إكسابهن المهارات اللازمة التي يتطلبها سوق العمل، و عمل دراسات مسحية للوظائف التي تشغلها العمالة غير السعودية في جميع القطاعات لمعرفة الاتجاه اللازم اتخاذه لإحلال القوى العاملة السعودية. للوفية

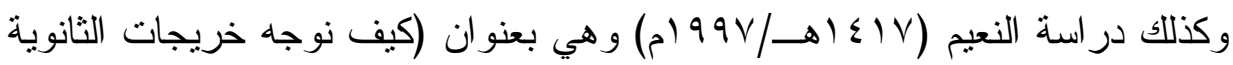

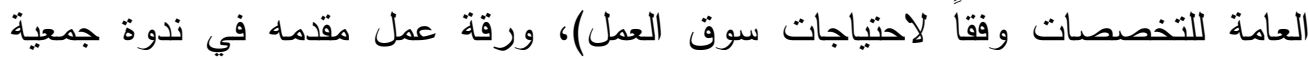

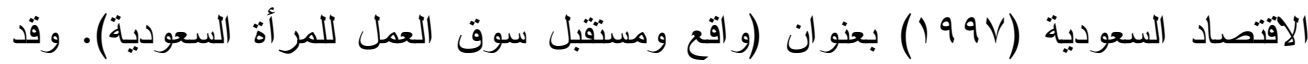


بينت الورقة أن التعليم الثانوي بوضعه الحالي يرتبط بالتعليم الجامعي أكثر من ارتباطه

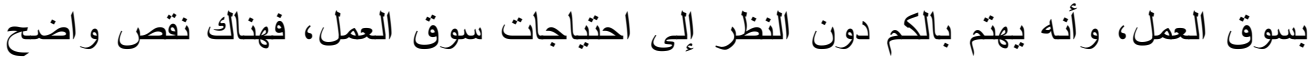

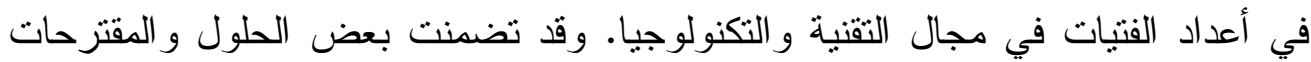
منها ربط الخطط الثزبوية بخطط التتمية وباحتباجات القطاعات المختلفة من التخصصات لتوزيع الطالبات على فروع الدراسة الملائمة و المؤهلة بعدة طرق منها: نوفير الإحصاءات و البيانات الكاملة عن احتباجات السوق في مجال الوظائف النسائية. وعقد ندوات متعددة

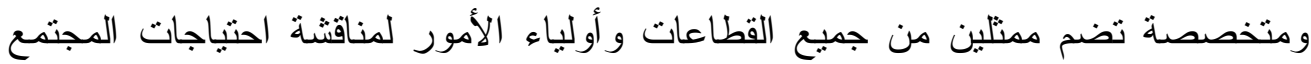
السعودي، و إنشاء كليات مهنية بعد الثنانوية لمدة سنتين تمنح دبلوم تخصص مهني، وبناء

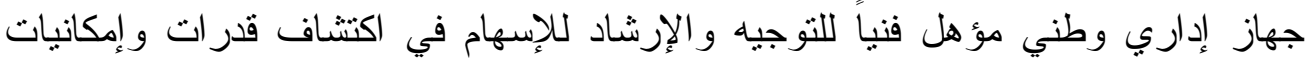
وميول الطالبات.

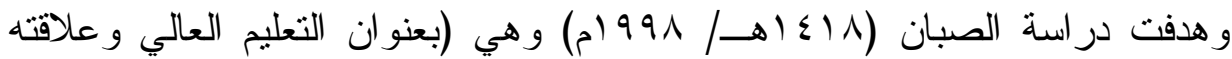
بسوق عمل المرأة في مدينة مكة المكرمة: أنموذجاً عن المملكة العربية السعودية) إلى الى

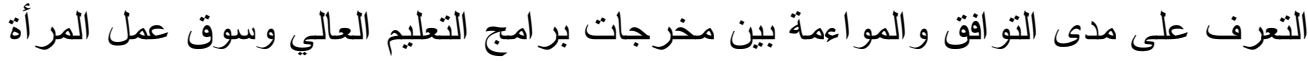
في المملكة بشكل عام وفي مدينة مكة المكرمة بصفة خاصة. و استخدمت الدر اسة المنهج الوصفي بحدودة المعروفة و انتهت الدراسة إلى أنه يوجد

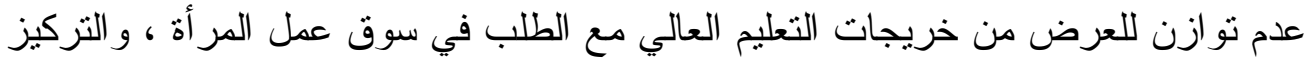
على التعليم النظري دون التطبيقي وعدم الاهتمام بالجانب الحرفي و التقني. وقدمت الدر اسة

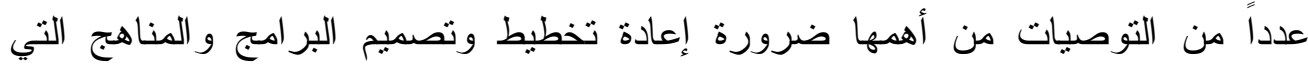

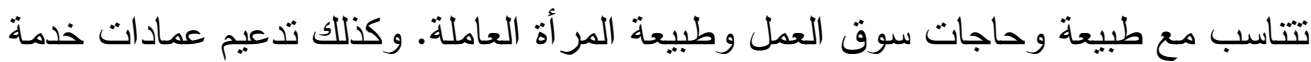
المجتمع و التعليم المستمر و استحداثها في الجامعات التي لانوجد بها. وهنالك دراسة قناديلي، جو اهر بنت أحمد. وهي بعنوان (مدى إسهام تعليم المرأة أهاة

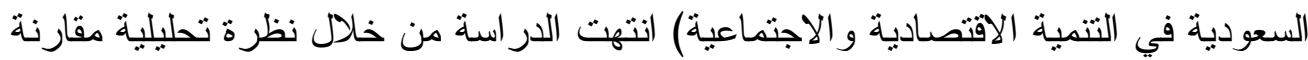

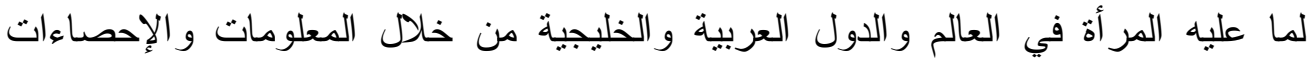
المختلفة إلى مجموعة من الاستتناجات كانت على النحو الآتي:

- توفر للمر أة السعودية فرص التعليم و العمل دون التعرض للاضطهاد أو بذل الكر امة.

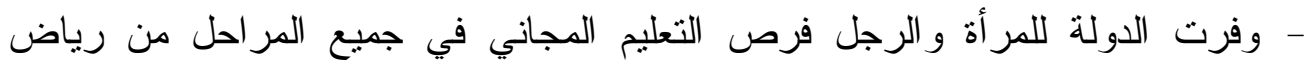

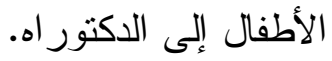
- نوفر الدولة فرص العمل للمرأة بما بيتاسب وطبيعتها مع عدم الاختلاط أو مزاولة الأعمال الثاقة أو الخطرة. 
- تشارك المر أة والرجل في المملكة العربية السعودية في فرص التعليم وفي الراتب على التى حد سواء، في جو إسلامي بعيد عن الاختلاط. - للمر أة السعودية مكانتها الاجتماعية الخاصة بها من احتر ام وتقدير من قبل أسرتها ومن الأن

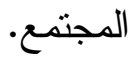
- تشارك المرأة زوجها في رعاية الأسرة و الأبناء، وغالباً ما تجدها مسئولة بشكل كامل عن رعاية المنزل و الأو لاد. - تفوق المر أة السعودية مثيلاتها في الدول النامية في نسبة المتعلمات إذا ما قورنت بالفترة الزمنية القصيرة. - المر أة السعودية ساهمت مع الرجل في التتمية الاقتصادية و الاجتماعية في ظل التعاليم الإسلامية.

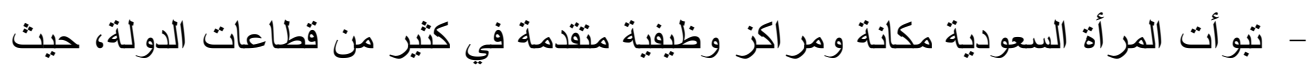

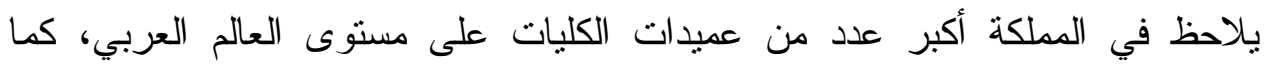

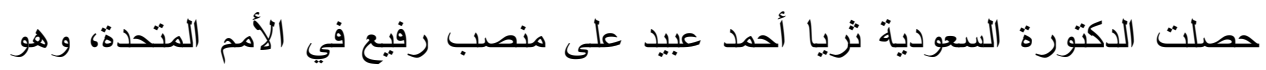

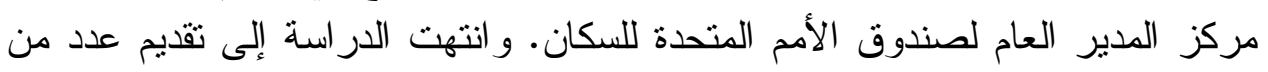
التوصيات تمثلت بما يأتي:

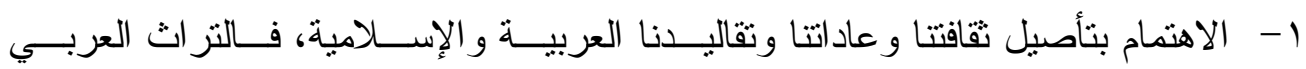
الإسلامي ينصف المر أة ويعلي من قيمتها.

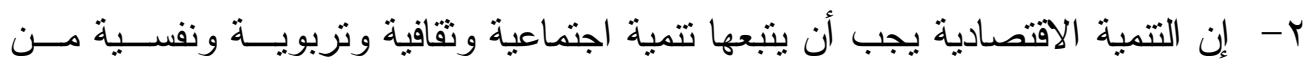
خلا القضاء على القيم الطبقية الأبوية.

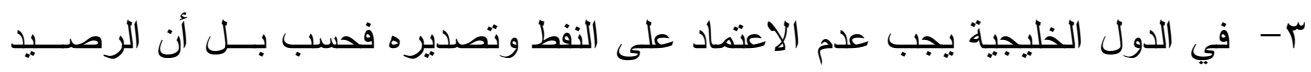
النفطي مهدد بالنفاذ، لذا يجب التوسع في الصناعات غير البتروكيماويـــة و البتروليـــة. و التوسع في الإنتاج الزر اعي و الصناعي، ويجب تدريب النساء في كافة المجالات.


تحقيق الضمان الاجتماعي لها حتى تتمكن من تأدية واجباتها على الوجه الأكمل.

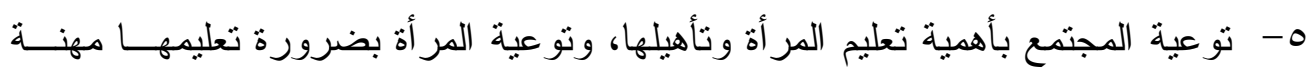
تساعدها على مو اجهة الحياة وذللك عن طريق وسائل الإعلام المختلفة.

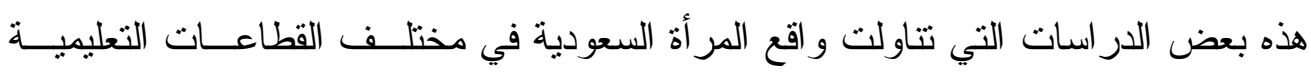
و الاقتصادية. 


\section{مشكلة الدر اسة}

لم يحظ موضوع تمكين المرأة في مجال التعليم بشقيه العام والعالي في المنطقة

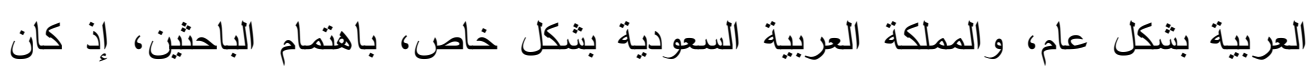

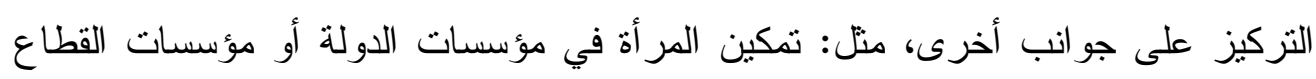
الخاص.

ونظر اً لأهمية الدور الذي يمكن أن ثقوم به المرأة السعودية في كافة المؤسسات،

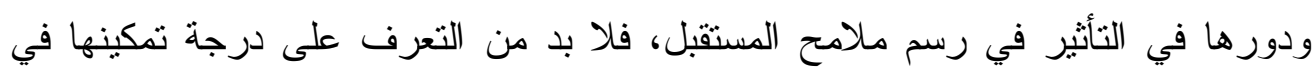

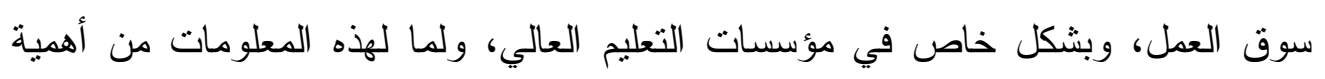
بالغة لأصحاب القرار في صناعة القرار ات التي تسهم في الحد من المشكلات التي تعاني

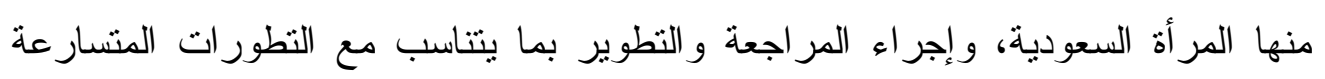

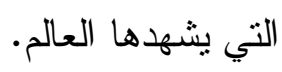

\section{أهمية الدر اسة}

تأتي محاولة الباحثة في إجر اء هذه الدراسة، التي تتبلور حول محاولة الكثف عن

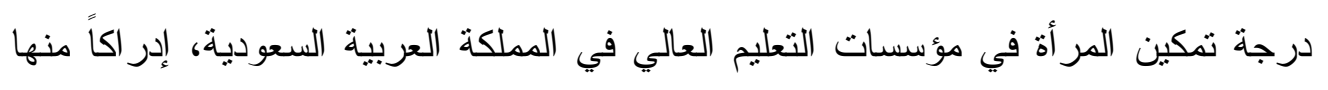

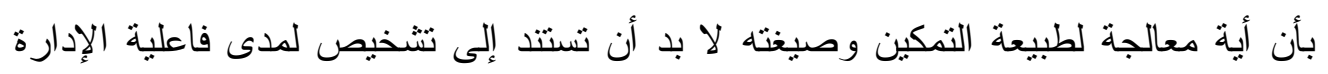
الجامعية التي تقوم بتفعيل عمليات و إجر اءات التمكين.

وبناءً على ما سبق، نتبع أهمية هذه الدر اسة من كونها تبحث في و اقع تمكين المر أة

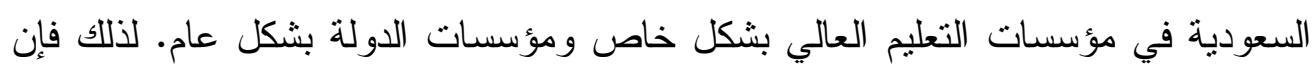

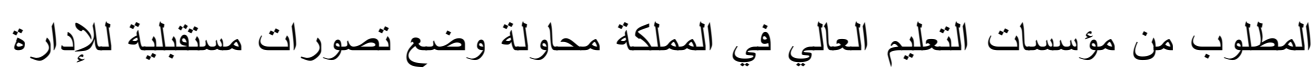

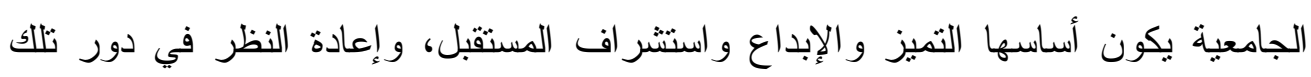
المؤسسات والأهداف التي تسعى إلى تحقيقها، و إعادة النظر في سياستها، و استر اتيجياتها،

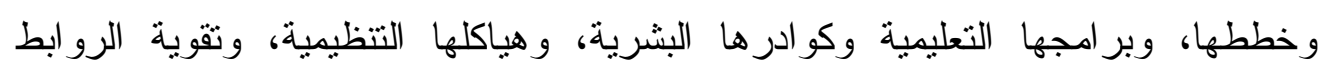
و العلاقات بينها وبين المجتمع والبيئة المحيطة، إضافة إلى ذلك تحقيق التفاعل الإيجابي بينها وبين ما يجري حولها من متغير ات وتحو لات عميقة. 


\section{أهداف الدر اسة}

تهدف الدراسة إلى تحقيق هدفين رئيسين هما هدف علمي وآخر عملي، وذلك على

$$
\text { النحو الآتي: }
$$

ا. تهدف الدراسة على المستوى العلمي إلى إلقاء الضوء على واقع تمكين المرأة

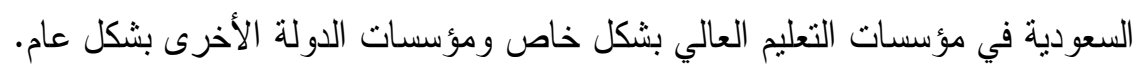
r. أما على المستوى العملي فتهدف الدراسة إلى لفت نظر أصحاب القر ار في التعليم

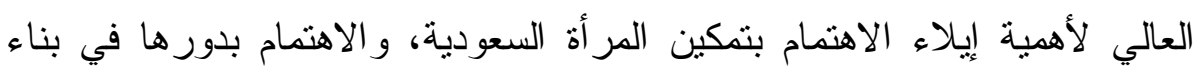
المجتمع. ومن اجل ذلك حاولت الدراسة تحقيق الأهداف الفرعية الآتية:

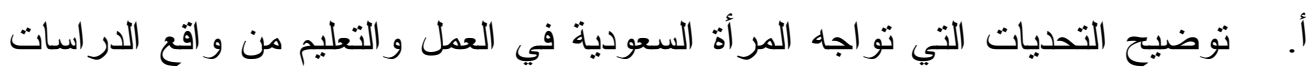
المبدانية.

ب. تسليط الضوء على واقع المرأة السعودية في مؤسسات التعليم العالي (طالبة أو (أكاديمية).

ج. تسليط الضوء على و اقع المر أة السعودية في مؤسسات الإنتاج الأخرى.

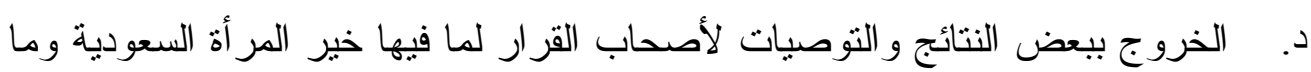
يبنى عليه من نتائج وأثز ايجابي في بناء المجتمع السعودي.

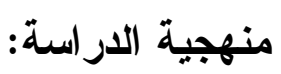

تمنل هذه الدراسة نظرية (مكتبية) تعتمد بالدرجة الأولى على المنهجين الوصفي

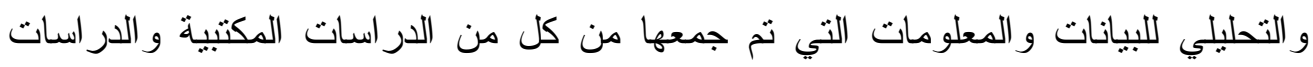

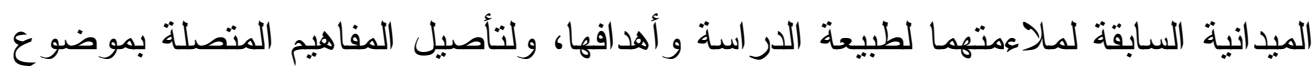

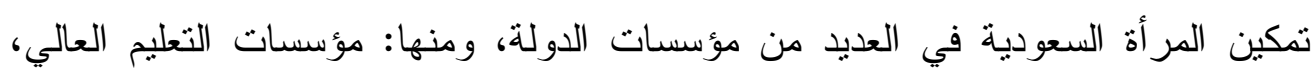
معتمداً على أحدث الأدبيات في هذا المجال، وذللك عن طريق الإطلاع على الإحصائيات

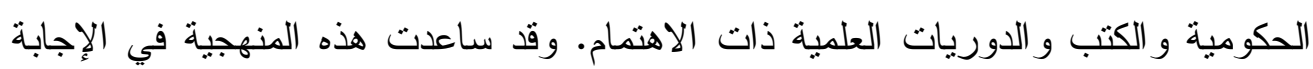

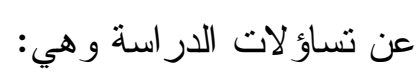

1. ما أهم التحديات التي تو اجه المر أة السعودية في المملكة العربية السعودية؟

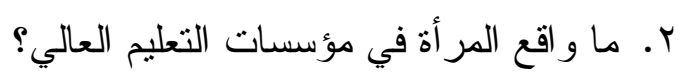

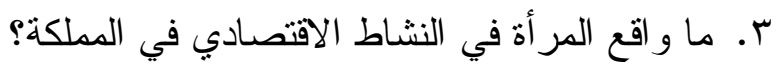


التحديات التي تواجه المر أة السعودية في العمل والتعليم

بعد مر اجعة الأحكام الخاصة بتعليم المر أة في المملكة بمكن ملاحظة الآتي:

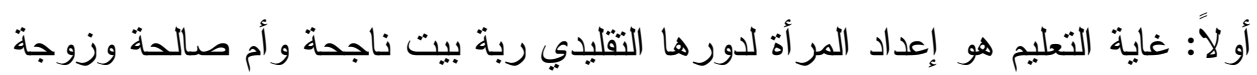

$$
\text { مثالية. }
$$

ثانياً:هناك طبيعة خاصة للمر أة بوصفها جنساً تختلف عن غيرها وتفرض هذه الطبيعــة

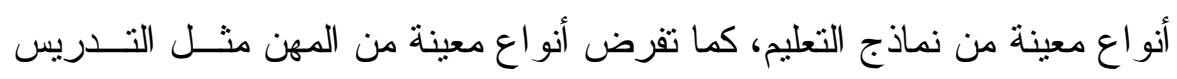

$$
\text { و التمريض. }
$$

ثالثاً:التأكيد على حق المر أة في التعليم وحرص الدولة على تـــوفير كافـــة الإمكانــات

$$
\text { اللازمة لذلك. }
$$

رابعاً:طبيعة التتظيمات التزبوية و الإدارية داخل هذه المدارس لا تحــددها الاعتبــار ات

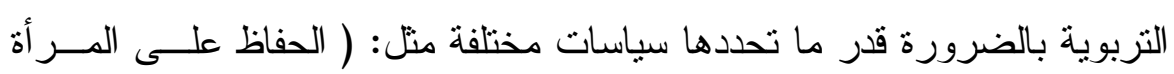

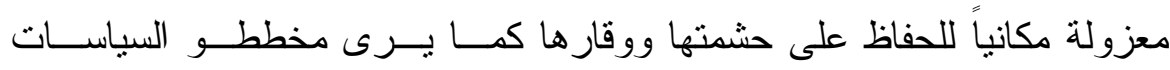

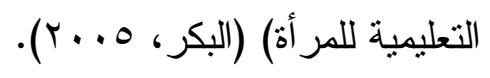

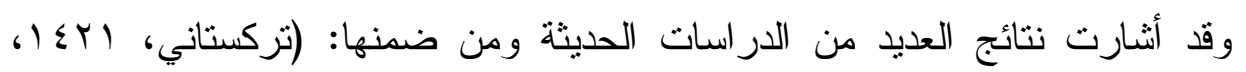

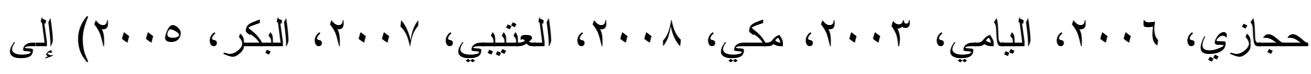
جملة من التحديات التي نو اجه المر أة السعودية تمنعها من الانخر اط في سوق العبا، العمل، منها:

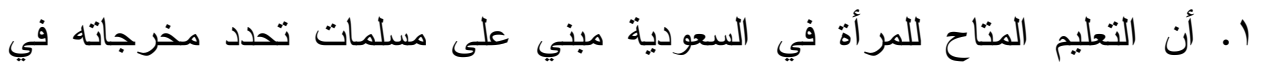



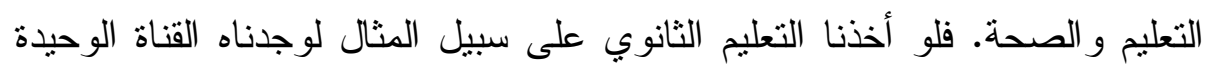

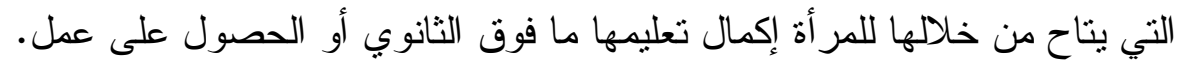

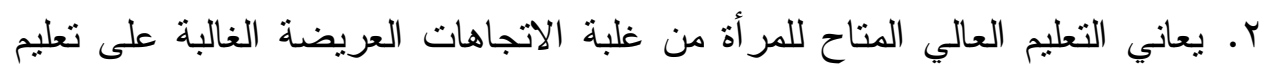

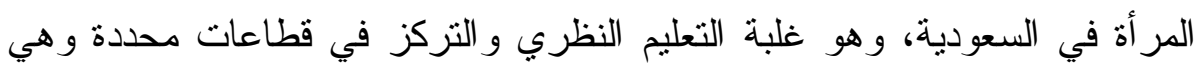

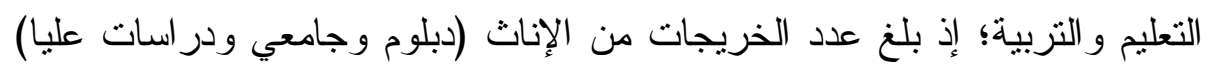

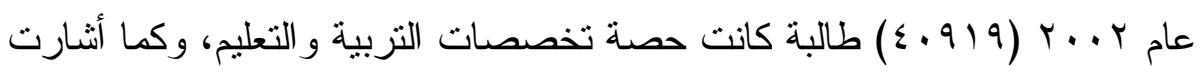

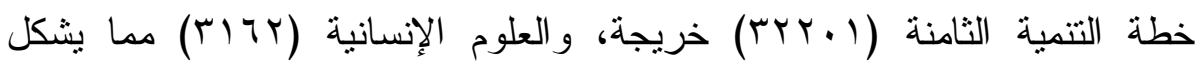

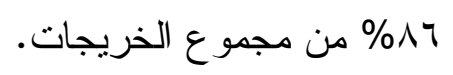


r. أن القطاعات المذكورة والتي أعدت النساء للعمل فيها من خلال مؤسسات التعليم

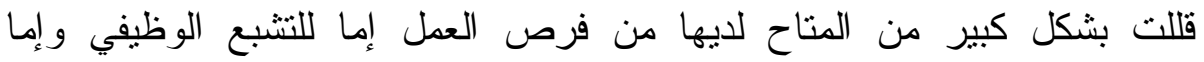

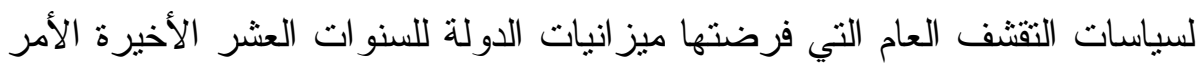
الذي ولد طو ابير العاطلات عن العمل. ع. مناهج تعليم المر أة في المدارس و الجامعات: فقد أظهرت العديد من الدراس استات عدم تو افق المقررات العملية في برامج مرحلة البكالوريوس و الإمكانات و القدرات الجسمية وحاجات الطالبات، لا تتو افق و التتشئة الأسرية و الأوضاع الإلية الاجتماعية لهن

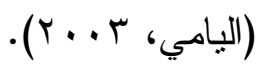

ه. يؤدي تقليص القنوات التعليمية وحصرها في مهن محددة (التدريس على وجه

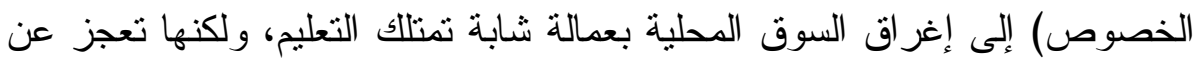

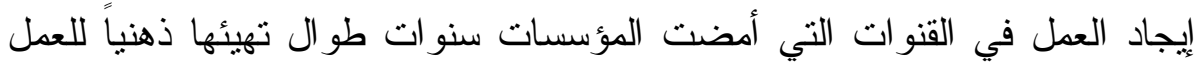
فيها وتدربها عليها عملياً داخل جدر انها. الأمر الذي أدّى إلى ارتفاع نسب التب البطالة

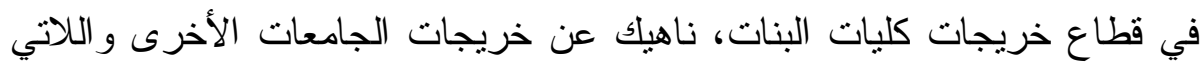

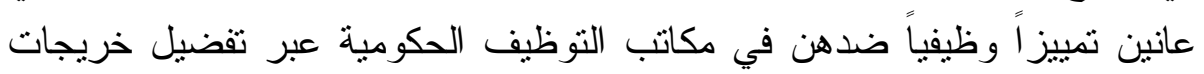

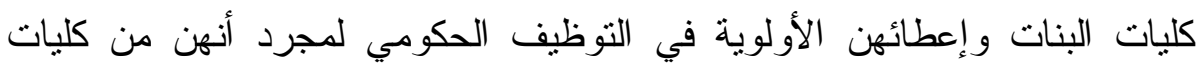

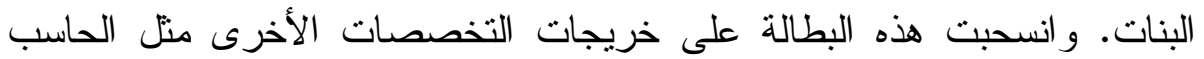

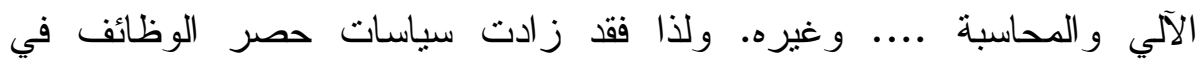
تخصصات معينة إلى إغلاق سوق العمل الكبير أمام المرأة، كما حرمها إلى حدات حدان

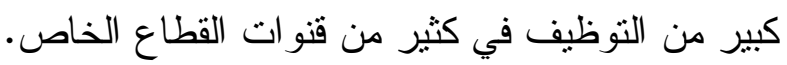
T. هنالك خلل واضح في العلاقة بين مخرجات التعليم وحاجات خطط التئمية



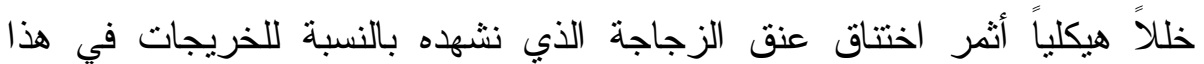

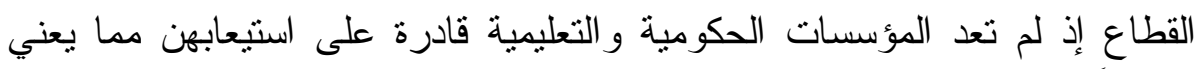

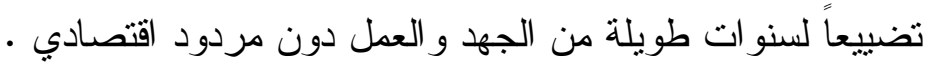

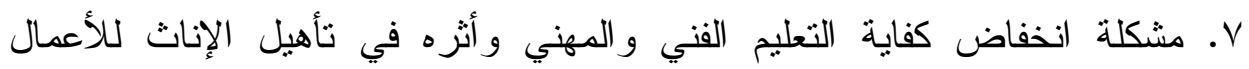

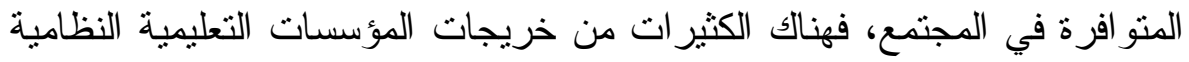

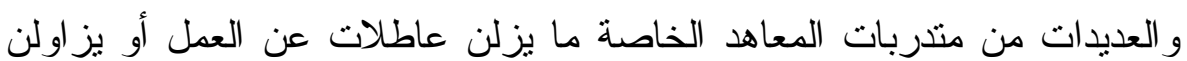

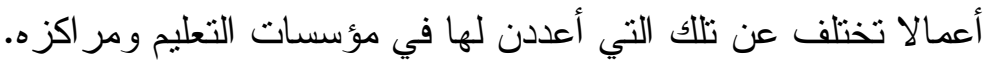

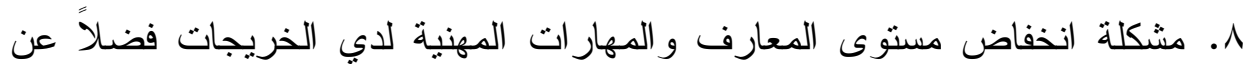
ضمور الاتجاهات و الميول الايجابية نحو العمل اليدوي. 
9. مشكلة قصور مؤسسات التعليم والتدريب المهنيين القائمة علي جذب الفتيات و الكبير ات للالتحاق بها. فالخريجات من المدرسة المتوسطة لا ير غبن في الالتحاق بالتعليم الثانوي المهني ويفضلن الالتحاق بالثانوي العام .ولهذا فإنهن لا يلتحقن

$$
\text { بالمدرسة المهنية إلا اضطر اراً. }
$$

• (.تحديات بنيوية تعكس طبيعة المجتمع التقليدية المعاكسة أحياناً لولوج المرأة المجال

$$
\text { التربوي و الاقتصادي. }
$$

11 ا.هنالك عو ائق التشريعات وتتمنت في قوانين الأحوال الثخصية، و التعاميم

$$
\text { و التوجيهات التي تحجب عن المر أة كثير اً من الحقوق. }
$$

r ا.تعرض معظم من شملتهن الدراسات إلى موضوع المحرم و الوكيل، بوصفه أحد

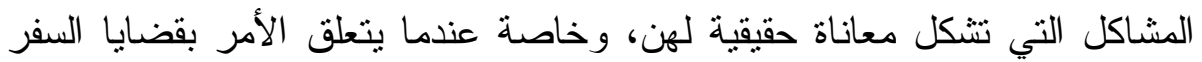

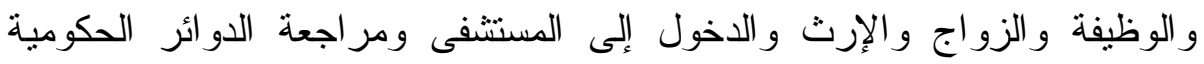

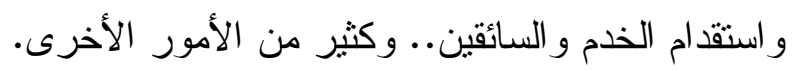

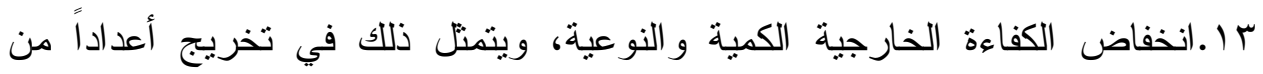
الخريجات في تخصصات لا يحتاجها سوق العمل مع وجود عجز وطلب في

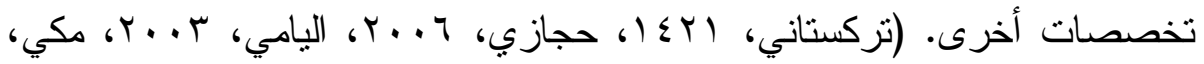

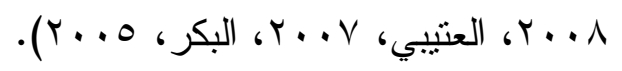

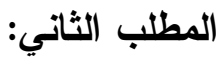

واقع المرأة السعودية في مؤسسات التعليم العام والعالي:-

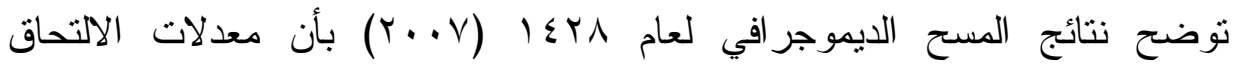

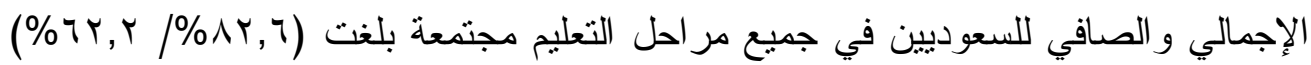
على الترنيب في حين تزيد معدلات الالتحاق الإجمالية للسعوديين الذكور بالمرحلتين

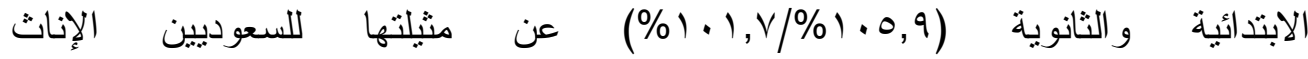


وربما يعزى ذللك إلى استمر ار الإناث في التعليم إلى مرحلة التعليم العالي في حين يلتحق الته جزء من الذكور بسوق العمل بعد إنهاء المرحلة الثانوية. 
ويوضح جدول (1) الزيادة المتوقعة في عدد الطلاب المتوقع تخرجهم من السعوديات

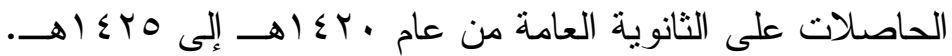

(1) الجدول (1) (1)

تقدير مخرجات التعليم الثانوي العام في المملكة العربية السعودية

$\rightarrow$ () $\leqslant 0-\rightarrow 1 \leqslant r$.

\begin{tabular}{|c|c|c|c|c|c|c|}
\hline \% سنة من & مجموع & \% سنة من & إناث & \% من سنة & ذكور & السنو ات \\
\hline $1 \ldots$ & $1 V 770$. & $1 \ldots$ & $99,7 \leqslant r$ & $1 \ldots$ & $V V, \ldots V$ & $01 \leqslant r$. \\
\hline $110, r$ & $r \cdot r, r q$. & $11 \leq$, & $11 \%, 094$ & $11 \mathrm{~V}$, & $9 \cdot, \cdot 9 \mathrm{~V}$ & $01 \leq r 1$ \\
\hline . & $r r \varepsilon, 991$ & $\mid r \cdot, \cdot$ & $1 Y q, \leqslant 97$ & $1 \pi 4,9$ & $1 \cdot 0, \leqslant 10$ & $01 \leqslant Y r$ \\
\hline $10 r, \varepsilon$ & $r v \cdot, 97 r$ & $1 \leq \Lambda, r$ & $1 \leq V, \pi Y 7$ & $17 \cdot, r$ & צחו, & $01 \leqslant Y T$ \\
\hline$I V V$, & $T I Y, 09 V$ & 171,9 & $17 \Lambda, Y 9 \leq$ & $\mid \wedge V, \varepsilon$ & $1 \leqslant \varepsilon, r \cdot r$ & $01 \leq r \leq$ \\
\hline$r \cdot \Sigma, r$ & r., & $19 r, 0$ & 191,100 & $r \mid 9, r$ & 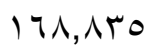 & $01 \leqslant r_{0}$ \\
\hline
\end{tabular}

في جدول (1) تم حساب الإسقاط بناءً على منوسط معدل النمو للسنوات

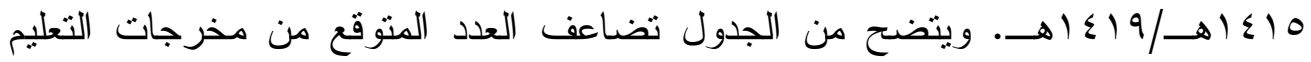

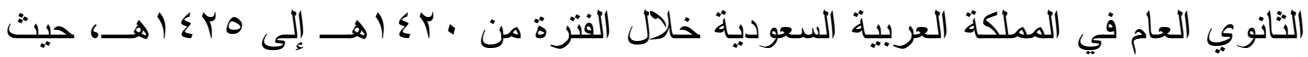

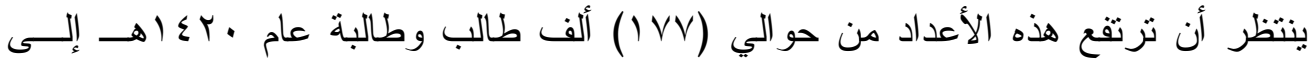

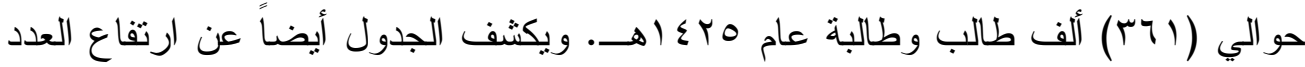

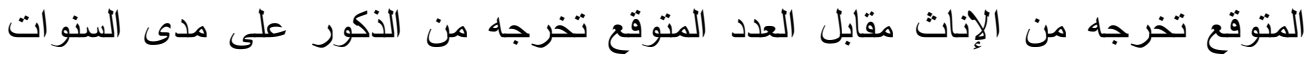

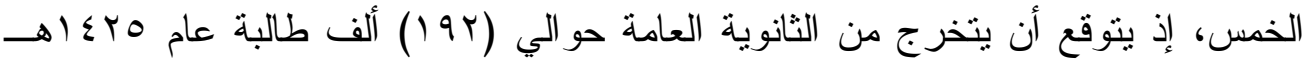

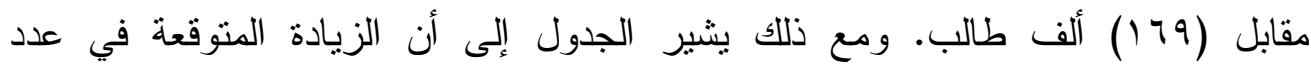

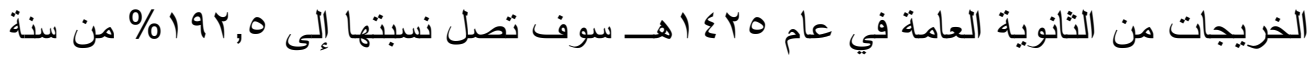

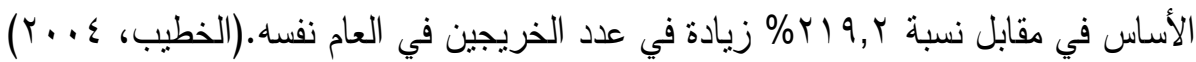
ومما لا شك فيه أن التحاق المر أة بالتعليم العالي يعد من إحدى الركائز الرئيسة التي تتيح للمر أة السعودية المساهمة الفعالة في تتمية المجتمع. وهنا يتبادر إلى الذهن التساؤل لهائل عن عدد الفتيات السعوديات في الفئة العرية الموازية للتعليم العالي (9 (19 ب سنة) لتتضح أمام الحوار الوطني ضخامة المهمة الملقاة على مؤسسات التعليم العالي في المملكة العربية 
السعودية لإتاحة فرص التعليم العالي للمر أة السعودية؛ فإذا أراد المجتمع أن ينمي قدر اتها الابتكارية وتزويدها بمهارات استخدام البحث العلمي و إنتاج المعرفة والإسهام في خدمة مجتمعها. ويوضح الجدول رقم (Y) عدد الإناث في الفئة العمرية الموازية للتعليم العالي مقارنة بعدد الذكور من السكان الوطنيين في المملكة العربية السعودية عام • بـ اهـ.

$$
\text { الجدول (r) }
$$

عدد الإناث من السكان السعوديين في الفئة العمرية الموازية للتعليم العالي

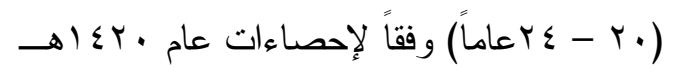

\begin{tabular}{|c|c|c|c|}
\hline \% من عدد الذكور في & \% من مجموع الفئة العمرية & العدد & النوع \\
\hline$\% \backslash \backslash \leqslant, \vee$ & $\% \circ r, \varepsilon$ & $\neg \wedge \neg, \cdot V Y$ & إناث \\
\hline \multirow[t]{2}{*}{$1 \ldots, \cdot$} & $\% \leqslant 7,7$ & $09 \wedge, r \vee V$ & ذكور \\
\hline & $1 \cdots, \cdot$ & $1, Y \wedge \leq, \varepsilon \leq q$ & ل لمجموع \\
\hline
\end{tabular}

المصدر : وزارة التخطيط، ·r أهـ، ص r ب.0.

ويكثف الجدول (r) ارتفاع نسبة الإناث في الفئة العمرية الموازية للتعليم العالي

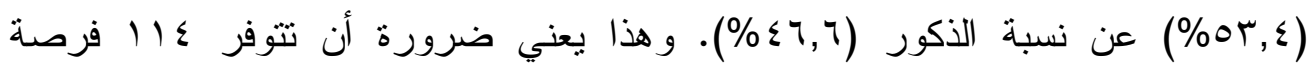

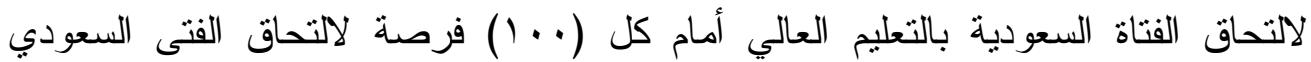
بالتعليم العالي إذا أردنا تطبيق مبدأ تكافؤ الفرص التعليمية بالتعليم العالي في ضوده بـاء معيار النمو السكاني.

كما يوجد أكبر عدد من الطلبة المقيدين في مجال إعداد المعلمين بنسبة (TrV, T)

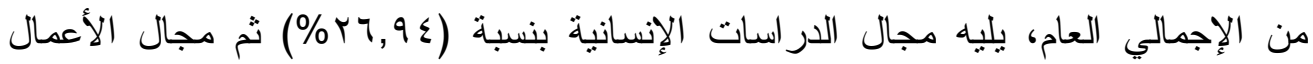
التجارية و الإدارية بنسبة (r/, • (\%). ومن ناحية تقسيم النسب السابقة بين الذكور و الإناث

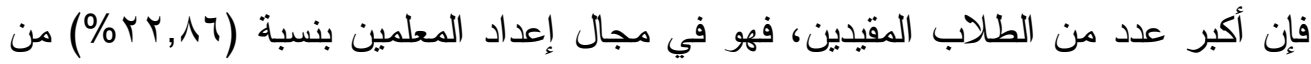

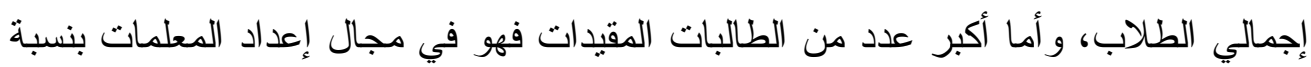

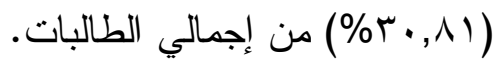




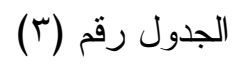

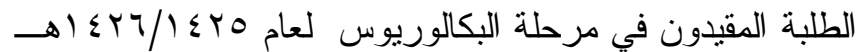

\begin{tabular}{|c|c|c|c|c|}
\hline النسبة (\%) & جملة & طالبات & طلاب & مجال الدر اسـة \\
\hline 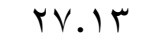 & $1.01 \vee 0$ & VTMT & r900 & إعداد المعلمين \\
\hline ᄉ.. $\varepsilon$ & MTV & rTะYA & $\vee q \leq q$ & علوم التزبية \\
\hline r.. $9 \leq$ & $1.010 \mathrm{r}$ & $\Lambda \cdot \Sigma T r$ & $r \leqslant V Y$. & الدر اسات الإنسانية \\
\hline r.9r & $10 r \cdot 1$ & $117 r 0$ & سוT & العلوم الاجتماعية و السلوكية \\
\hline r.90 & $11 \leqslant 99$ & $\varepsilon \cdot 7 \leqslant$ & $v \leqslant$ To & الصحافة و الإعلام \\
\hline $1 . . v r$ & $\S) \wedge \neg \wedge$ & $19 \Lambda \mathrm{TV}$ & Yr. $\varepsilon l$ & الأعمال التجارية والإدارة \\
\hline r. $\varepsilon\rceil$ & $\mid r \leqslant q 1$ & $1 \cdot Y \wedge 7$ & o & العلوم الفيزيائية \\
\hline$V .0$ & rVOrt & $r \cdot \leq \cdot 0$ & VITV & الرياضيات و الإحصاء \\
\hline דr. & 11.97 & 7194 & 79.1 & المعلوماتية \\
\hline $1.0 r$ & 0940 & 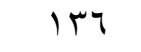 & $0 \vee 99$ & الهندسة و الصناعة الهندسية \\
\hline.$v r$ & rᄉOr & rAOr & - & الصناعات الإنتاجية و التحويلية \\
\hline . .ی & Tros & - & Tros & الرندسة المعمارية و البناء \\
\hline T.re & $M \cdot \varepsilon r$ & $0 \leqslant \leqslant V$ & 1090 & الصحة \\
\hline $1 \cdots$ & rq. rAr & $r 71.1 \mathrm{~V}$ & 149470 & الإجمالي \\
\hline
\end{tabular}

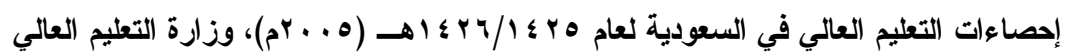

يتبين من الجدول السابق أن الطالبات المقيدات في مجالات الدراسة السابقة بلغت نسبتهن نحو (V7V\%) ثقريباً من إجمالي المقيدين في مرحلة البكالوريوس، في حين الطلبة في هذه المجالات بلغت نسبتهم (سr\%) تقريباً، إلا أن الطالبات المقيدات يشكلن الأغلبية في المجالات المذكورة في الجدول وهذا يرجع إلى ارتفاع عدد المقيدات في مجالات إعداد المعلمات و علوم التربية و الدراسات الإنسانية و العلوم الاجتماعية والسلوكية و الأعمال التجارية و الإدارية.

ومن أهم ما يلاحظ على الجدول أيضاً أن نسبة الطلاب المقيدين في المجالات العلمية، منل: الهندسة بأنو اعها و الصحة ضئيلة إذ بلغت نحو (\%,V) من إجمالي الطلبة المقيدين في المجالات المذكورة في الجدول. 


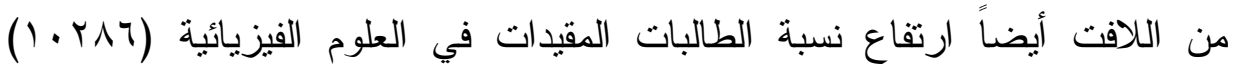

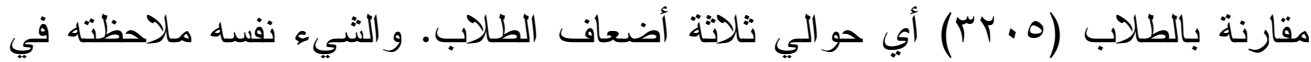

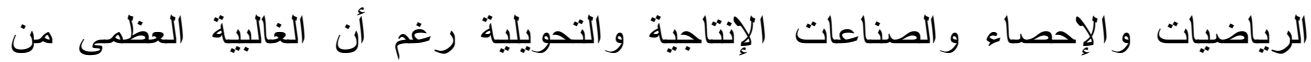
خريجات التعليم العالي في المملكة لا تقيد قوة العمل بالاقتصاد السعودي (العتيبي، V. . ب؟).

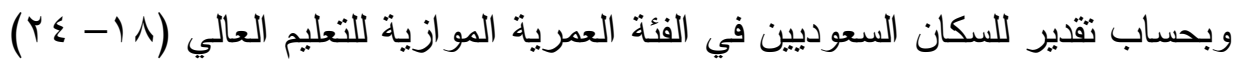
خلال الفترة من عام · ...rم إلى عام 10 • بم، و الجدول رقم (ع) يوضح ذللك الثقدير .

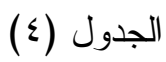

تقدير السكان في الفئة العمرية المو ازية للتعليم بالمملكة العربية السعودية

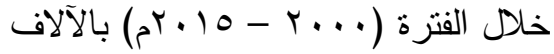

\begin{tabular}{|c|c|c|c|c|}
\hline $5+10$ & $5_{r \cdot 1 .}$ & $a_{r}$ & r. & الفئة العمرية 1 | - ؟ ب سنة \\
\hline 1781 & lorv & ITIV & $1 \cdot \Sigma$ & إناث \\
\hline $1 v 00$ & $171 \leq$ & irqr & $11 \cdot r$ & ذكور \\
\hline$r \leqslant r V$ & r101 & $r V \cdot q$ & $r_{1} \leq 1$ & المجموع \\
\hline
\end{tabular}

المصدر : [الفارس، 1991، ص 117]. ويكثف الجدول (ع) عن الزيادة الهائلة المتوقعة في الفئة العمرية الموازية للتعليم

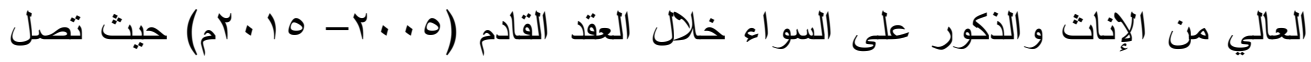

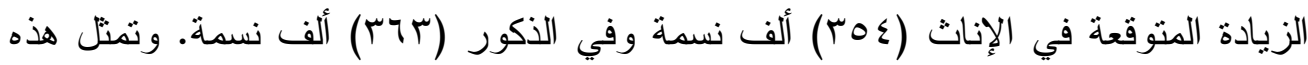

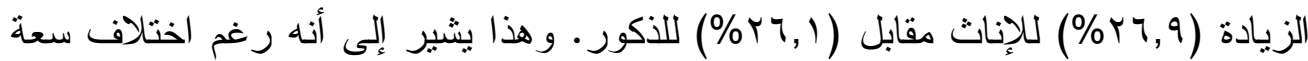

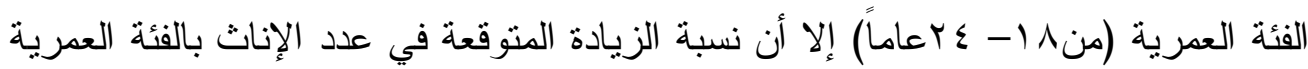

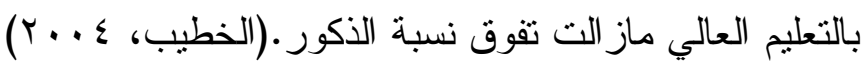
ويؤكد هذه الزيادة العددية في الفئة العمرية الموازية للتعليم العالي من عدد الفتيات السعوديات مؤشر إحصائي آخر هو نسبة مخرجات التعليم الثانوي العام هـن البنات مقابل البنين. وبالر غم من زيادة أعداد الطالبات في التعليم العالي عن البنين، إلا أن مشاركة المرأة

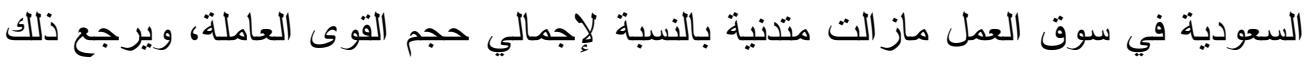

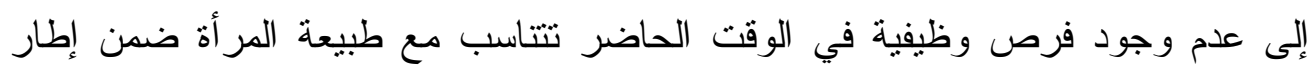

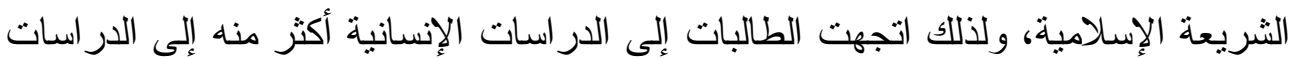

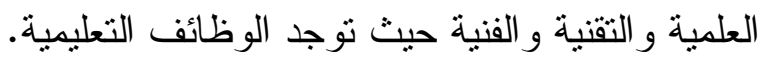


و الجدول (0) يوضح النمو الكمي لعدد الطالبات المقيدات في برنامج الدراسات العليا بدرجتي الماجستير و الدكتور اه في الجامعات السعودية وفي كليات البنات الجامعيات. الجدول (0)

النمو الكمي للطالبات المقيدات بالدر اسات العليا في الجامعات السعودية وكليات البنات

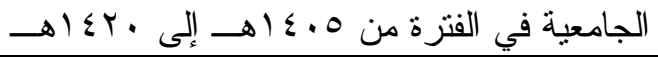

\begin{tabular}{|c|c|c|c|c|c|}
\hline معدل النمو السنوي & $1 \leq r$. & $1 \leqslant 10$ & $1 \leq 1$. & $1 \leq .0$ & الدرجة العلمية \\
\hline$\%) \leq, \leq$ & $10 V 0$ & 1 rot & VMT & Ort & ماجستير بالجامعات السعودية \\
\hline$\% \vee, 7$ & Tו & rat & וl & rAV & ماجستير بكليات البنات \\
\hline$\% 1 \cdot, V$ & $10 \leqslant$ & 199 & $1 \leqslant 9$ & 09 & دكتور اه بالجامعات السعودية \\
\hline$\% r \cdot, 1$ & ratr & rVo & ron & 9 . & دكتور اه بكليات البنات \\
\hline$\% 11,9$ & $r V \cdot \varepsilon$ & $r .9 r$ & ITVE & $9 \wedge \wedge$ & المجموع \\
\hline
\end{tabular}

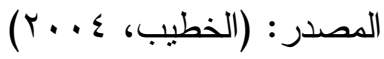

ويلاحظ أن النمو في معدلات القيد للبنات في كافة المراحل التعليمية تفوق معدلات

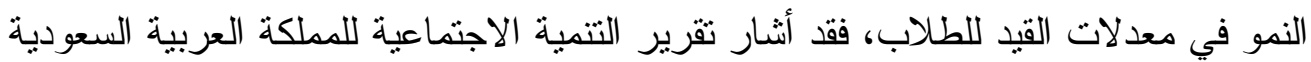

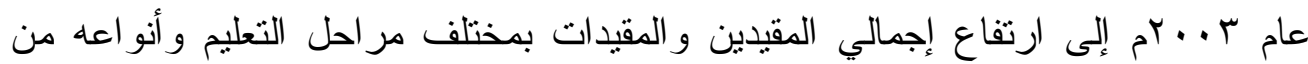

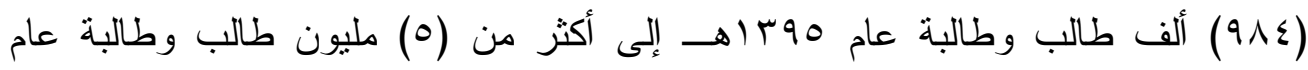

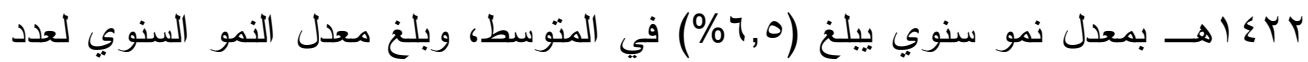

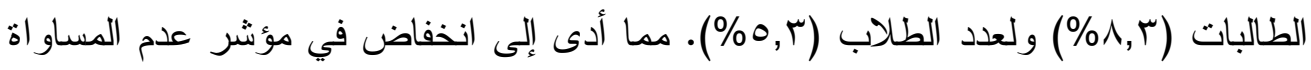

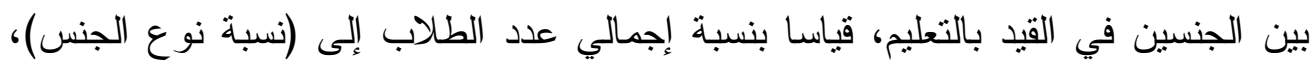

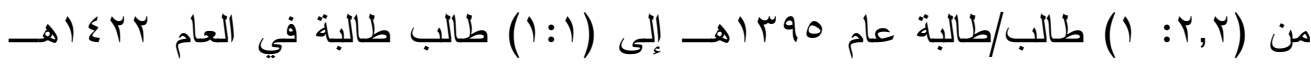

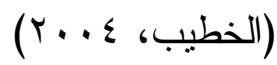
و الجدول (T) يوضح مقارنة القيد بين البنين و البنات في المرحلة الجامعية بين عامي

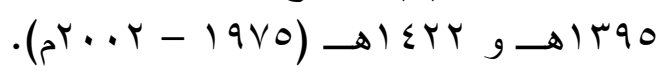

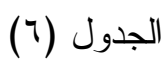

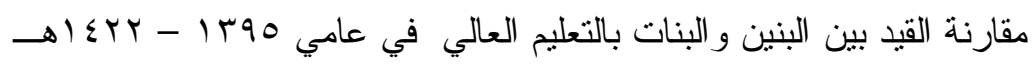

\begin{tabular}{|c|c|c|c|c|c|}
\hline \multirow{2}{*}{ السنوي النمو } & \multicolumn{2}{|c|}{$\rightarrow \mid \sum K r$} & \multicolumn{2}{|c|}{ ه } & \multirow{2}{*}{ القيد بالتعليم العالي } \\
\hline & $\%$ & العدد بالآلاف & $\%$ & العدد بالآلاف & \\
\hline$\% \wedge$ & $\leqslant \vee, \tau$ & TrY & $\wedge 1,7$ & rI & ذكور \\
\hline$\% \backslash \leq, \wedge$ & or, \& & rro & $1 \wedge, \varepsilon$ & v & إناث \\
\hline$\% 1 \cdot, r$ & $1 \ldots$, & $\sum \wedge V$ & $1 \ldots$, & rA & الدجموع \\
\hline & & $1: \cdot, 9$ & & $1: 1 \leqslant, \varepsilon$ & ـد الذكور لكل أنثى \\
\hline
\end{tabular}

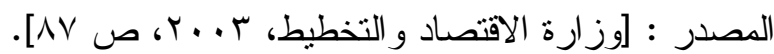


ويتضح لنا من جدول (T) التحسن الواضح في معدلات القيد للطالبات بالتعليم العالي سو اء على مستوى معدل النمو السنوي، حيث ارتفع ذللك النمو إلى (^,ـ (\%) للبنات مقابل (\%^) للبنين، أو على مستوى نسبة الذكور إلى نسبة الإناث بالتعليم العالي؛ إذ تتبر هذه

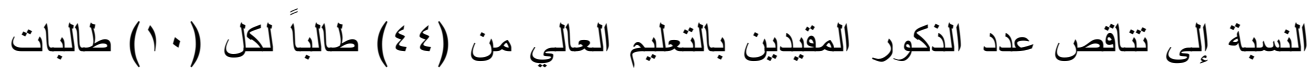

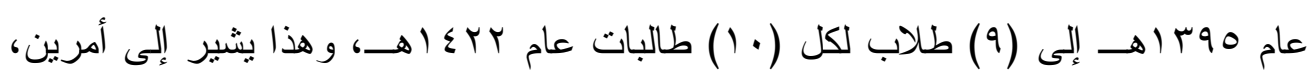
أولهما: حرص الدولة على توفير فرص الالتحاق بالتعليم العالي، والآخر الرغبة الطموحة لاى البنات لاستكمال در اساتهن الجامعية من ناحية أخرى. كما يتضح لنا من جدول (7) أن عدد الطالبات المقيدات بالدراسات العليا سواء في

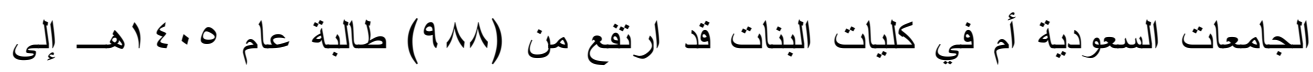

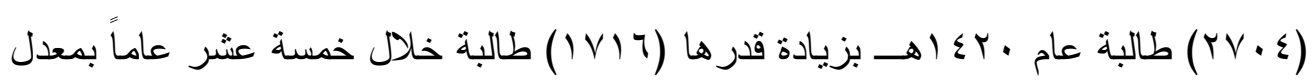

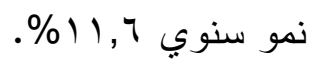

كما يلاحظ - أيضاً - أن عدد الطالبات المقيدات لدرجة الدكتور اه بكليات البنات أعلى منه في الجامعات السعودية. في حين أن عدد الطالبات المقيدات لارجة الماجسنير في الجامعات السعودية أعلى منه في كليات البنات. وربما يعزى ذلك إلى حاجة كليات البنات إلى عضوات هيئة تدريس من العنصر النسائي، و إلى تبني الجامعات السعودية الابتعاث الخارجي لعدد من الحاصلات على درجة الماجستير و إلى قلة البرامج المتاحة للاكتور اه في الجامعات السعودية مقارنة ببر امج الماجستير • بمقارنة المقيدين من الطلبة والطالبات في مرحلة البكالوريوس عام .باء اهـ. ويتضح لنا في الجدول أي التخصصات أكثر إقبالاً من الطالبات، وأيها أقل إقبالاً من فئن الطالبات. و الجدول يوضح توزيع قيد الطلبة والطالبات على التخصصات المختلفة بالتعليم

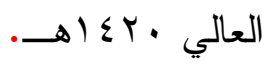


(v) (الجدول

توزيع الطلبة و الطالبات المقيدين بالتعليم العالي على التخصصات المختلفة

\begin{tabular}{|c|c|c|c|c|c|c|}
\hline \multicolumn{2}{|c|}{ المجموع } & \multicolumn{2}{|c|}{ إناث } & \multicolumn{2}{|c|}{ ذكور } & \multirow{2}{*}{ التخصص } \\
\hline$\%$ & عدد & $\%$ & عدد & $\%$ & عدد & \\
\hline$Y, V$ & NYVT & $1, \cdot$ & rוץ & $1, V$ & $0.7 \pi$ & العلوم الطبية \\
\hline r,o & 1.007 & - & - & $r, 0$ & 1.007 & العلوم الـندسية \\
\hline$O V, Y$ & $1 V \varepsilon \varepsilon Y$. & $\leqslant 0$, & $|M V \cdot \varepsilon|$ & $1 Y, r$ & rVTVq & التربية و التعليم \\
\hline r & r人r & $\cdot, \varepsilon$ & $1 \cdot \lambda \varepsilon$ & $\cdot, 9$ & rVTV & العلوم الزراعية \\
\hline $0, \xi$ & $17 \leqslant 91$ & $1, \wedge$ & orvE & r, & $111 K \varepsilon$ & العلوم الطبيعية \\
\hline $1, \varepsilon$ & \& & $\cdot, \cdot 7$ & $1 \wedge 1$ & $1, \varepsilon$ & $\leqslant 179$ & الاقتصاد و الإدارة \\
\hline$\varepsilon, 9$ & $1 \leq \wedge \circ Y$ & $\cdot, 7$ & 19.0 & $\varepsilon, \Gamma$ & $14 q \leq V$ & العلوم الاجتماعية \\
\hline 11,1 & 円イ夫. & $r, V$ & מדזה & $\Lambda, \varepsilon$ & roT.V & الدر اسـات الإسلامية \\
\hline $1 Y, 0$ & r人lor & $0, \Lambda$ & $1 \vee \wedge \leqslant 0$ & $7, V$ & $r \cdot r \cdot V$ & العلوم الإنسانية \\
\hline $1 \cdots$, & T. $\varepsilon \vee 70$ & ov, r & $1 \vee \leqslant \wedge \vee 7$ & $\varepsilon Y, V$ & 1 1 $q \wedge \wedge q$ & المجمو ع \\
\hline
\end{tabular}

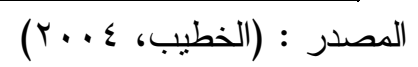

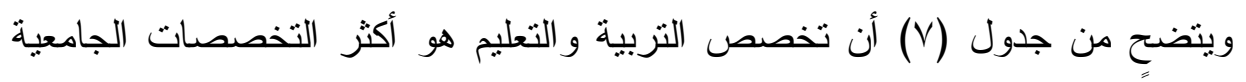

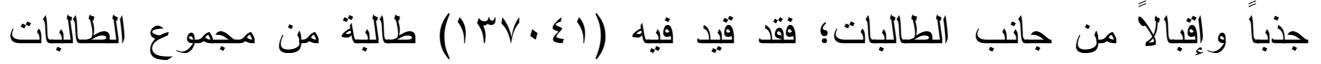

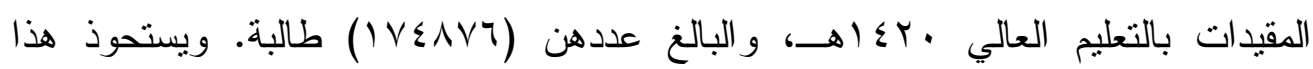

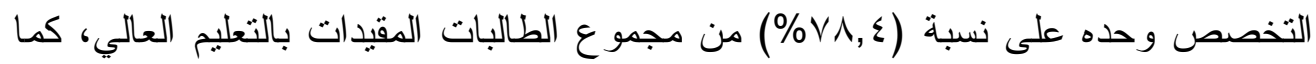

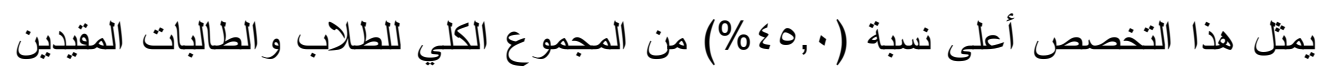

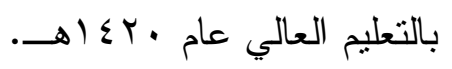

ويأتي تخصص العلوم الإنسانية في الترتيب الثاني لإقبال الطالبات المقيدات بالتعليم

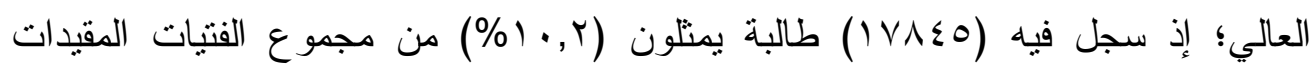

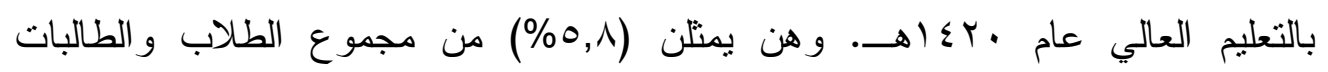
المقيدات بالتعليم العالي في العام نفسه.

ويأتي تخصص الدراسات الإسلامية في الترتيب الثالث لإقبال الطالبات المقيدات

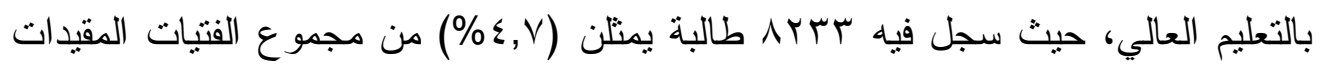

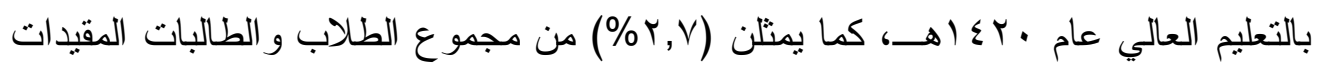
بالتعليم العالي في العام نفسه. 
ويكثف جدول V) أن التخصصات الثلاثة (التربية و التعليم، و العلوم الإنسانية،

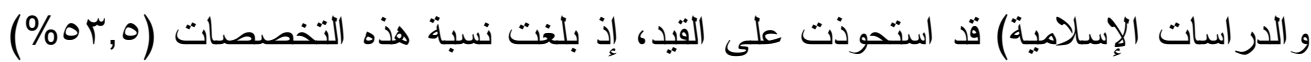

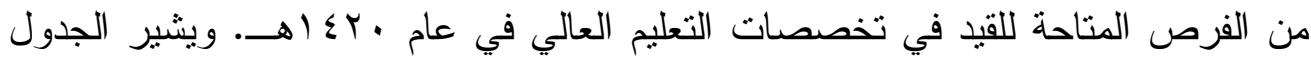

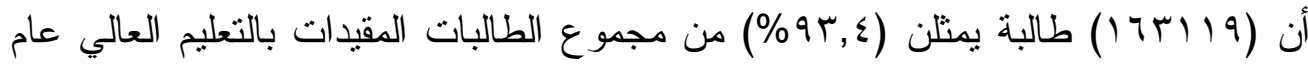
• بـ ا هـ اخترن هذه التخصصات الثناث على التو الي: التربية و التعليم، و العلوم الإنسانية، و الدر اسات الإسلامية.

ويكثف جدول (V) - أيضاً - أن أقل التخصصات إقبالاً من جانب الفتبات المقيدات

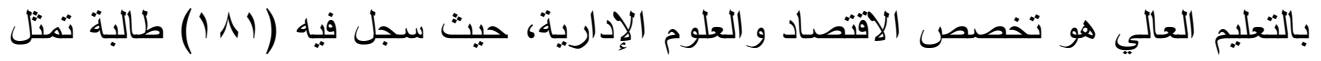

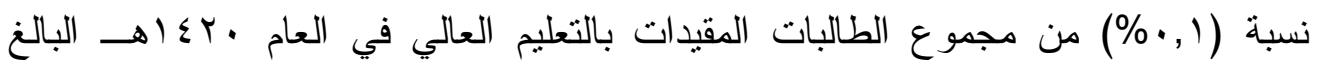

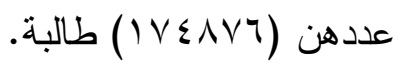

ويليه تخصص العلوم الزراعية؛ فقد سجل فيه (£ی • ( ) طالبة يمثلن (7, • \%) من

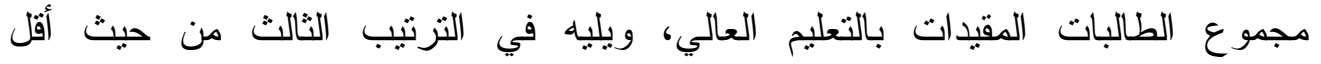
التخصصات التي تجذب الطالبات للتشجيل فيها؛ تخصص التصات العلوم الاجتماعية؛ فقد سجل فيه فيه

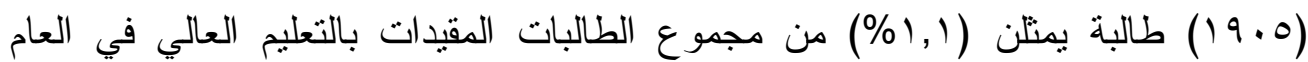



و الملاحظ ن التخصصات الثلاثة (الاقتصاد والإدارة، و العلوم الزراعية، و العلوم

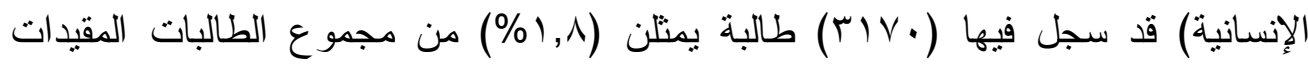

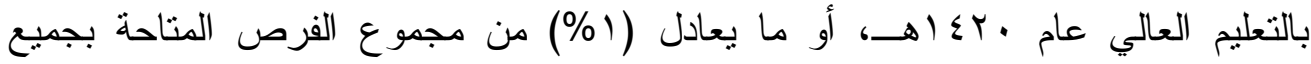

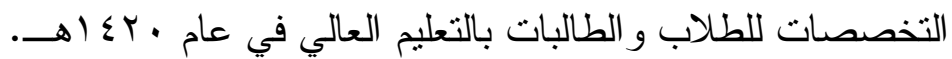
و الثابت أن التخصصات التي تستحوذ على إقبال الطالبات بالتعليم العالي هي المناظرة

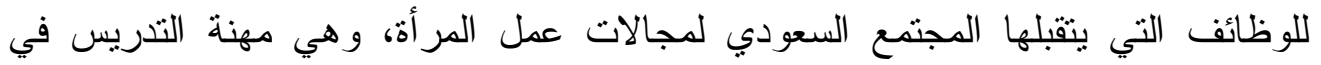
مدارس البنات وبعض الخدمات الاجتماعية، في حين توجد بعض كليات غير متاحة أمام

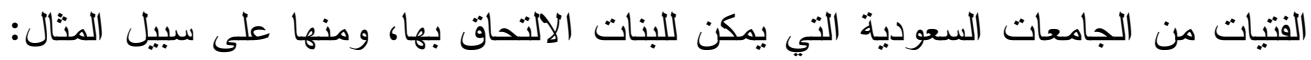
كلية الهندسة وكلية العمارة و التخطيط ومعهد اللغة العربية بجامعة الملك سعود، وكلية علوم

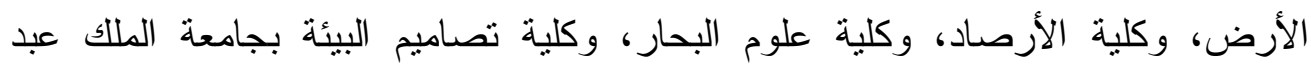
العزيز ، وكلية العلوم الإدارية و التخطيط، وكلية الطب البيطري ولادية ولثية الثروة الحيو انية بجامعة الملك فيصل، وكلية التمريض بجامعة الملك خالد، وكلية الهندسة ومعهد اللغة العربية بجامعة أم القرى. 
عمل المرأة وتخصصات التعليم:يوضتح الجدول (^) تطور العمالة النسائية السعودية ونسبتها من مجموع القوى العاملة

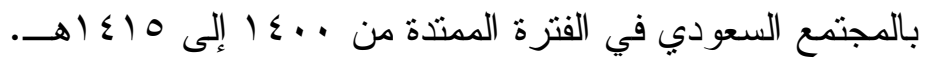
(^) الجدول (^)

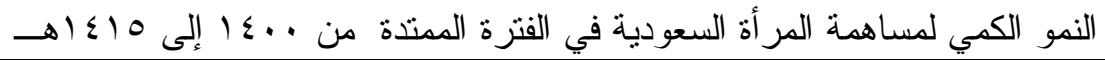

\begin{tabular}{|c|c|c|c|c|}
\hline$\$ 1 \leqslant 10$ & ه إ. & ( ) & هـ... & مؤشر عمل المر أة السعودية \\
\hline 99.91. & r.... & r709... & YI. K. E. & المو اطنات في سن العمل \\
\hline r10... & $1719 \ldots$ & 1 rฯa.. & I. T... & القوى العاملة النسائية السعودية \\
\hline$\% 0,0$ & $\%$ & $\% 0,1$ & $\% \leqslant, 9$ & نسبة التحاق المرأة السعودية بسوق \\
\hline 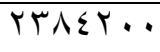 & $19110 \ldots$ & 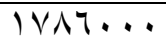 & $1 \leq 9 \leq \wedge \leq$. & جملة القوى العاملة السعودية \\
\hline$\% 9, \cdot$ & $\% \wedge, 0$ & $\% \vee, V$ & $\% 7,9$ & نسبة مساهمة المرأة السعودية في \\
\hline 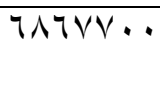 & $7 . \leq 9 \leq \ldots$ & or $\leqslant \leqslant 7 \ldots$ & $r . r \neg \ldots$ & السعودي القوى العاملة في المجتمع \\
\hline$\%$ & $\% r, \wedge$ & $\% r, 7$ & $\%$ $\%, \varepsilon$ & نسبة مساهمة المر أة السعودية في \\
\hline$\%$ & \% & $\% \div \leqslant, 1$ & $\% \leqslant 9, \varepsilon$ & القوى العاملة بالمجتمة العمالة السعودية في \\
\hline
\end{tabular}

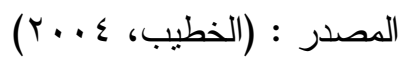

وتثير إحصاءات القوى العاملة السعودية إلى أن المر أة تشارك في مجالات الخدمة المدنية سو اء في الوز ارات و المصالح الحكومية أو في المؤسسات العامة، ويتصدر قطاع التعليم المجالات التي تعمل فيها المرأة السعودية؛ فقد بلغ عدد النساء السعوديات اللائي

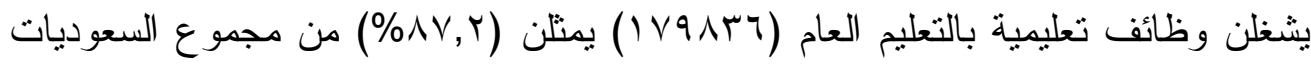

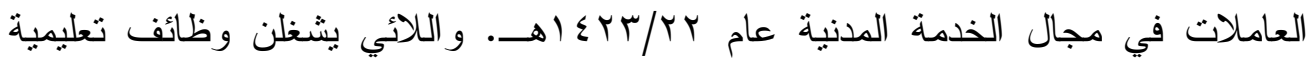
بالتعليم العالي (عضوات هيئة تدريس ومحاضر ات ومعيدات) بلغ عددهن (ror) ويمثلن $\cdot(\%), \wedge)$

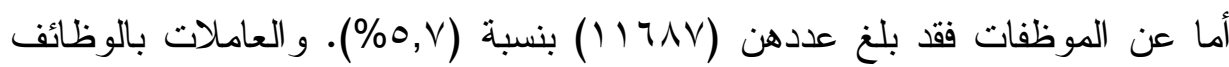

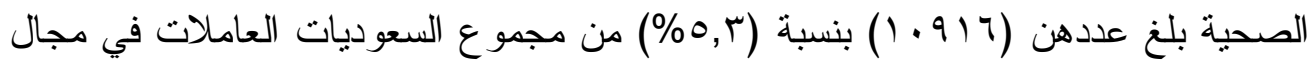

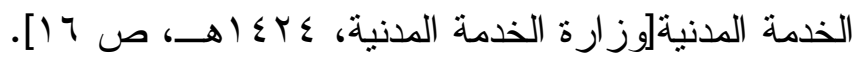
وتقدر نسبة النساء السعوديات العاملات بـ (00,ء \% \%) من إجمالي القوى العاملة. ويعتقد أن هذه المشكلة ناتجة من محدودية الفئات الوظيفية المتاحة للنساء في الاقتصاد. 
وفي الوقت الر اهن، بدأ النساء يعملن بصورة واسعة في قطاعات التعليم والصحة، الصاء

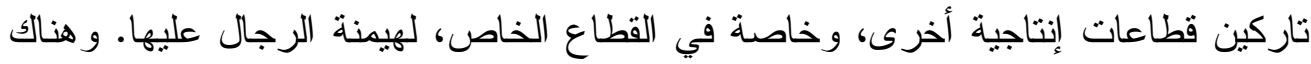

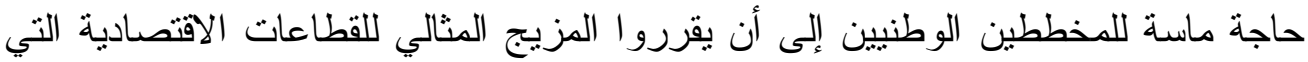


يوضح نسبة تركز المر أة السعودية في سوق العمل وفي وفقاً للمستوى التعليمي.

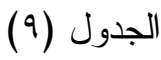

\begin{tabular}{|c|c|c|}
\hline نسبة الإناث إلى إجمالي المشتغلين & إجمالي عدد المشتغلين & المستوى التعليمي \\
\hline \%।r,r & $\varepsilon \vee 9.1$ & دكتور اه \\
\hline$\% \backslash r, \varepsilon$ & 91.40 & دبلوم عالي + ماجستير \\
\hline$\%$ Y०, . & $1 \mathrm{r} 9.70 \mathrm{~V}$ & بكالوريوس \\
\hline$\% \vee, 7$ & KOOV.r & الثانوية العامة \\
\hline
\end{tabular}

المصدر : (وز ارة التخطيط، ج ج. r) (بتصرف من الباحثة)

يظهر لنا جدول (9) نسبة تركز النساء المشتغلات بسوق العمل حسب المستوى

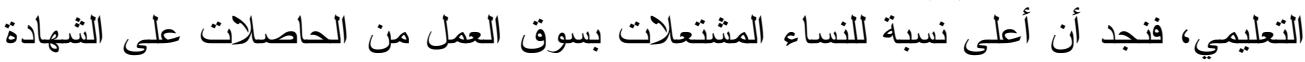

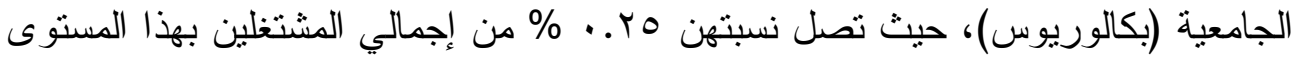

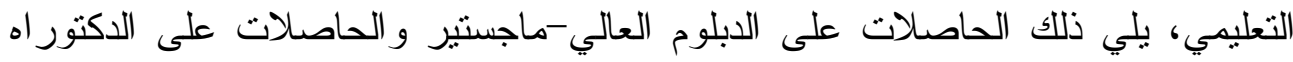

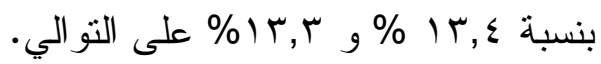
وبالنظر يظهر لنا جدول (· (1) يوضح تزكز المرأة السعودية في سوق العمل وفقاً ل اللنشاط الاقتصادي.

$$
\text { جدول (·) (1) }
$$

تركز الإناث السعوديات بسوق العمل وفقاً للنشاط الاقتصادي

\begin{tabular}{|c|c|c|}
\hline نسبة الإناث & إجمالي عدد المشتغلين & النشاط الاقتصادي \\
\hline$\% \leqslant 0,9$ & $9.81 \times 1$ & التعليم التيم \\
\hline$\%$ Y,$\vee$ & rTO\&QT & الصحة \\
\hline$\% \varepsilon, 1$ & 179101 & الخدمات الاجتماعية \\
\hline- & V9 $47 V$ & الكهرباء و الغاز و المياه \\
\hline$\% r, q$ & rOYT. T & الأنشطة العقارية \\
\hline$\% 70,7$ & $1 \leqslant Y 0997$ & الإدارة العامة \\
\hline$\% 1, \varepsilon$ & rqq & الزر اعة \\
\hline$\% \wedge$, Y & 1074 & المنظمات و الهيئات الدولية \\
\hline$\% 0,9$ & NTOV. & الوساطة المالية \\
\hline
\end{tabular}

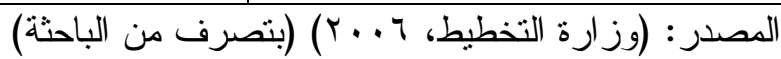


ونجد من الجدول السابق أن عمل المر أة السعودية يتركز في قطاع رئيس، وهو قطاع

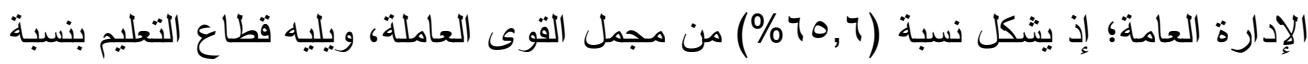

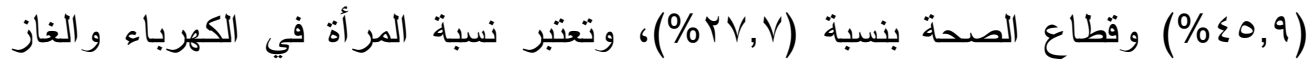

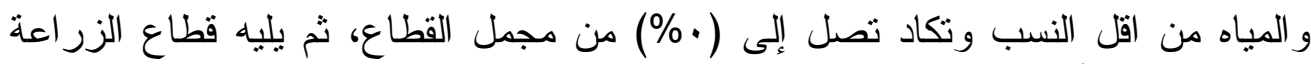
بنسبة متدنية جداً لا تتعدى (ع أ (\%) من مجموع العمالة في هذا القطاع . ويظهر لنا الجدول (1) (1) تركز الإناث السعوديات في سوق العمل وفقاً لنوع المهنة.

$$
\text { جدول (1) }
$$

تركز الإناث السعوديات بسوق العمل وفقاً لنوع المهنة

\begin{tabular}{|c|c|c|}
\hline نسبة الإناث & إجمالي عدد المشتغلين & نوع المهنة (العمل) \\
\hline$\% \wedge, 9$ & YV.VYr & المديرون ومديرو الأعمال \\
\hline$\%$ \%r,r & $019 \vee 17$ & الاختصاصيون في المو اضيع العلمية و الفنية و الإنسانية \\
\hline$\%$ \%ั, v & $\wedge \leq 7 \backslash \vee 1$ & الفنيون في المو اضيع العلمية و الفنية و الإنسانية \\
\hline$\%$ \%, & $0 \leq V Y \leq q$ & 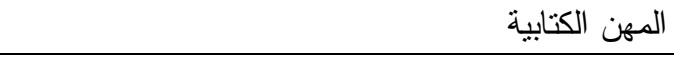 \\
\hline$\% 1, r$ & T9AYYA & العاملون بالبيع \\
\hline$\%$ \% 1,0 & $r \varepsilon \cdot V \tau \cdot r$ & العاملون في الخدمات \\
\hline$\% 1,0$ & r)A.r & العاملون في الزر اعة \\
\hline$\% \varepsilon, 0$ & $1 \wedge r \leq \varepsilon$. & مهن صناعية وكيمائية وغذائية \\
\hline$\% \cdot, r \wedge$ & $177 r 00$. & مهن هندسية أساسية \\
\hline
\end{tabular}

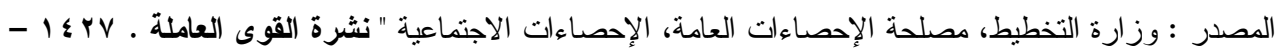
צ . . r (بتصرف من الباحثة) يتضح لنا مما سبق - بالنسبة للسعوديات - فقد اتضح أن ما نسبته نحو ( 9 \%) منهن من العاملات في المهن الفنية و العلمية، في حين أدنى نسبة للعاملات في المهن الهندسية، فقد بلغت (^r, • \% من المجموع. جدول (1) (1) (1)

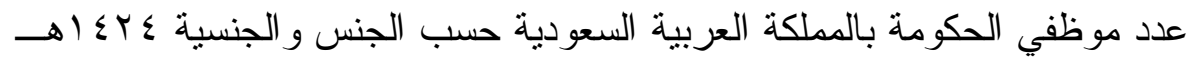

\begin{tabular}{|c|c|c|c|c|c|}
\hline \multirow{2}{*}{ إجمالي } & \multicolumn{2}{|c|}{ الغير مواطنون } & \multicolumn{2}{|c|}{ المو اطنين } & \multirow{2}{*}{ القطاع } \\
\hline & إناث & ذكور & إناث & ذكور & \\
\hline 11.1 .0 & $1 V .0$ & $0 \leqslant \leqslant \leqslant$ & 1 ro. 1 & $\mid 711 \leq 1$ & الموظفون العامون \\
\hline TANYTE & $1 \leq \leqslant \mu$ & & I NVOVO & $11000 \mathrm{r}$ & الوظائف التعليمية \\
\hline$\Lambda \cdot r \vee \leq$ & rTONV & |AKIA & $M \cdot V V$ & rqrar & الوظائف الصحية \\
\hline
\end{tabular}

المصدر : مركز الجيل للاستشار ات (0. . ب) 
و الجدول رقم (r () يوضح نزكز الإناث السعوديات في القطاع العام (الحكومي).

جدول (r)

تزكز الإناث السعوديات في القطاع العام (الحكومي)

\begin{tabular}{|c|c|c|c|c|c|}
\hline IVOVo & 977 & $r q . r$ & $\varepsilon r \cdot \tau$ & $\wedge \varepsilon, 1$ & أعضاء هيئة التذريس \\
\hline 1.41 & . & . & . & $1 \cdot \pi$ & 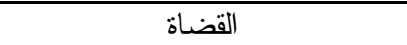 \\
\hline 1194 & . & . & . & 1194 & أعضاء هيئة التحقيق و الادعاء العام \\
\hline $77911 \%$ & $r V V \cdot I$ & \&IYYA & YITะTT & rATVIV & المجموع \\
\hline$\checkmark V \wedge 0 \leqslant$ & $\leqslant V$ & $\varepsilon \vee$. & $\wedge \varepsilon 99$ & 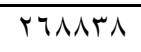 & المستخدمون \\
\hline$V \leqslant 7977$ & $r V V \leqslant \Lambda$ & $\sum 1791$ & $r Y \leq 970$ & $\leqslant 0 Y 000$ & الإجمالي \\
\hline & $\% r, v 1$ & $\% \otimes, 0 \wedge$ & $\% r \cdot, 1 r$ & $\% 7 \cdot, 09$ & \\
\hline \multicolumn{6}{|c|}{ الوظائف الصحلة الإحصيائية الرجال و النساء العاملين على السلالم التالية ( سلم رو اتب الموظفين العام ( مر اتـب )، ســلم } \\
\hline \multicolumn{6}{|c|}{ وظائف أعضاء الوظـف التعليمية، سلم وظائف أعضاء هيئة التذريس و المحاضرين و المعيدين، سلم وظائف القضـــاة، ســلم } \\
\hline \multicolumn{6}{|c|}{ هيئة التحقيق و الإدعاء العام وسلم وظائف المستخدمين ). } \\
\hline & & & & & المصدر: وزارة الخدمة المدنية. \\
\hline
\end{tabular}

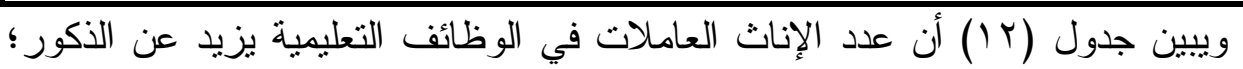

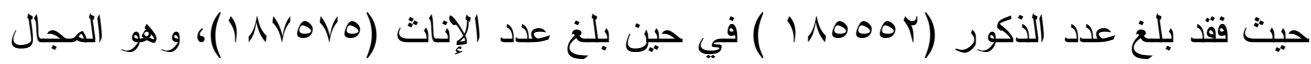

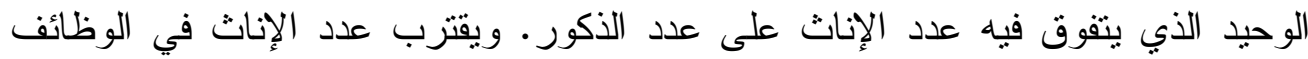

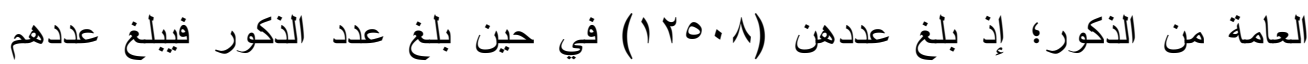

( $(17) 1 \leqslant 1)$

أما بقية الوظائف، فالعدد يميل إلى صالح الذكور بشكل عام. كما يبين الجدول رقم

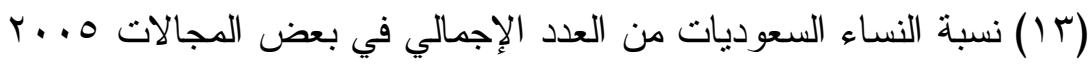

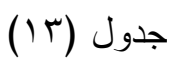

نسبة النساء السعوديات من العدد الإجمالي في بعض المجالات

\begin{tabular}{|c|c|c|}
\hline نسبة النساء السعوديات & الإجمالي & المسمى الوظيفي \\
\hline$\% \vee$, & 111701 & الموظفون العامون السعوديون \\
\hline$\% 01$ & rNV.07 & الوظائف التعليمية \\
\hline$\%$ \%. & $\leqslant 9199$ & الوظائف الصحية \\
\hline$\%$ \% & 1 rVOI & أعضاء هيئة التنريس و المحاضرين و المعيدين \\
\hline$\%$. & $r \leq 7$. & القضاة و أعضاء التحقيق و الادعاء العام \\
\hline
\end{tabular}

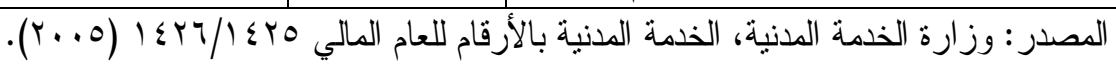

يتضح لنا من الأرقام و الإحصائيات الو اردة في الجداول (Y I) و (T ( )، أن مشاركة المر أة تغلب في سوق العمل في الدولة قطاع التعليم يليه القطاع الصحي، بينما جاءت نسبة الإدات 
عمل المر أة في القطاع الخاص منخفضة جداً ربما بسبب عدم تأهيل المر أة ولعدم وجود فرص التدريب و التأهيل في ذلك القطاع (منتدى الرياض الاقتصادي، ب . . ץ). ويوضح الجدول (ع () عدد أعضاء هيئة التنريس و الدحاضرين و المعيدين من الذكور

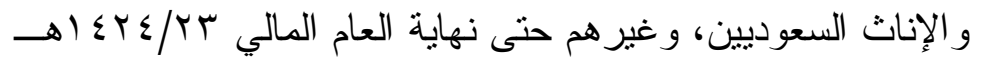

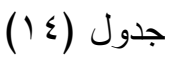

عدد أعضاء هيئة التدريس و المحاضرين و المعيدين من الأكور و الإناث

\begin{tabular}{|c|c|c|c|c|c|c|c|}
\hline \multirow{2}{*}{ المجموع } & \multicolumn{2}{|c|}{ غير سعودي } & \multicolumn{4}{|c|}{ سعودي } & \multirow{2}{*}{ البيان } \\
\hline & إناث & ذكور & $\%$ & إناث & $\%$ & ذكور & \\
\hline 1170 & VT & rAT & $\cdot, \varepsilon$ & 11 & $\Lambda, r$. & $7 \wedge 9$ & أستاذ \\
\hline I & $1 \leq \varepsilon$ & $\varepsilon \wedge \vee$ & $r, q$ & iro & $1 \leqslant, 7$ & ITYV & أستاذ مشارك \\
\hline OV 1 & $0 . r$ & 1094 & $r \cdot, \varepsilon$ & AVV & אז & TVV. & أستاذ مساعد \\
\hline 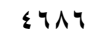 & VYr & $r \leq 71$ & $\%$ rr, & I. . . & $\% \diamond \diamond, \wedge$ & $\varepsilon \neg \wedge 7$ & المجموع \\
\hline rovt & Ir. & $q \cdot v$ & $r \wedge, \wedge$ & $I r \leq r$ & $10, \varepsilon$ & IraV & محاضر \\
\hline $01 . r$ & $11 \varepsilon$ & OrV & $\varepsilon \vee, 0$ & $r \cdot \varepsilon \varepsilon$ & $\lceil\wedge, \wedge$ & $r \leq 1 \wedge$ & معيد \\
\hline V & . & V & . & . & . & . & مدرس لغة \\
\hline IVovo & 977 & $r q \cdot r$ & $1 \cdots$, & $\varepsilon r \cdot T$ & $1 \cdots$, & $\wedge \varepsilon \cdot 1$ & المجموع \\
\hline
\end{tabular}

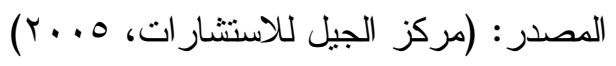

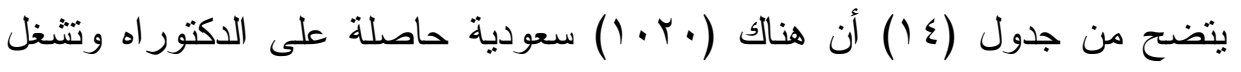

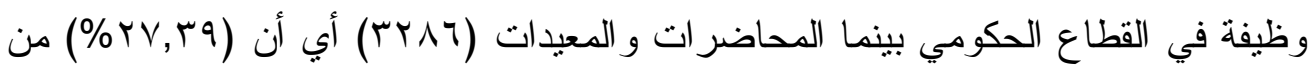
أعضاء هيئة التدريس الإنات المعينات في القطاع الحكومي من جامعات ومعاهد وكليات

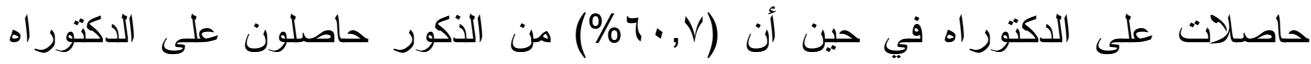

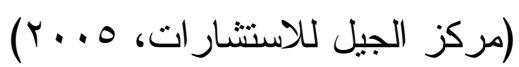
ونجد - أيضاً -أن المر أة وصلت إلى أعلى المراتب الأكاديمية، ولكن بنسب أقل من

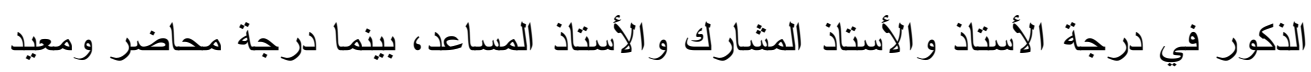
نجد نسبة الإناث فيها أعلى من الذكور ، وقد يعود ذلك لتوفر بر امج الماجستير في الجامعات

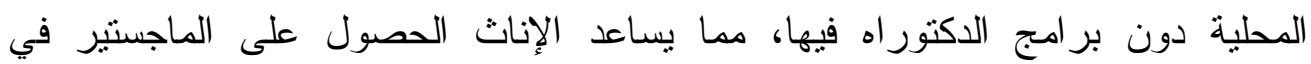
الجامعات المحلية بدون السفر إلى خارج المملكة. ومن الجداول السابقة نلاحظ أنه يغلب على مشاركة المر أة السعودية في القطاع العام تركز ها في قطاع التعليم، في حيت تتخفض نسبتهن في باقي الوظائف الأخرى. 
واقع المرأة في النثاط الاقتصادي في المملكة ألغت وزارة التجارة و الصناعة السعودية أخيراً شرط وجود الوكادي المعالة و الكفيل الغارم لسيدات الأعمال السعوديات، بعد أن كان إلز امياً في الفترات السابقة الفيقة حال تقدام سيدة الأعمال

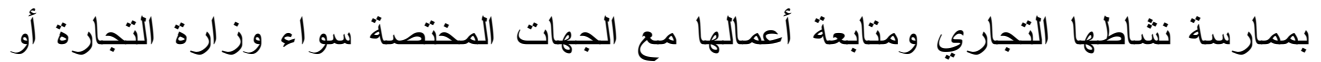
الغرف التجارية أو غير هما من الجهات.

وما يؤكد تجاوب الدولة مع تتامي حضور المر أة الاقتصادي؛ هو توجه وزارة التجارة

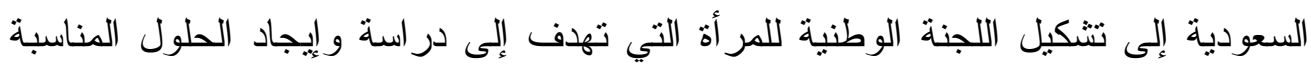



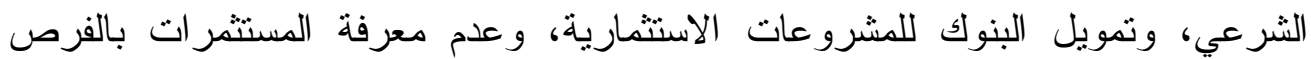
الاستثمارية .

وتشير سجلات وزارة التجارة والصناعة السعودية للتجارة الداخلية أن عدد السجلات

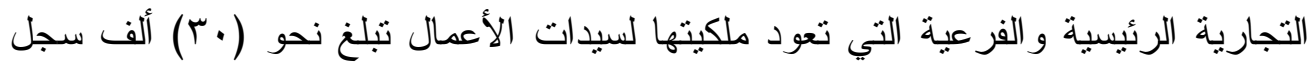

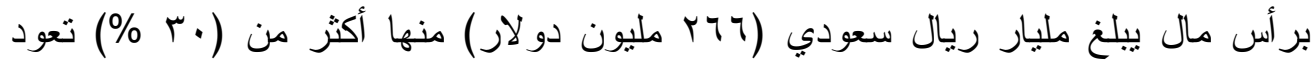
لسيدات الأعمال في مدينة الرياض. ملئ. وتبلغ نسبة مساهمة المر أة السعودية في إجمالي قوة العمل السعودية بنسبة (0,0\%)؛

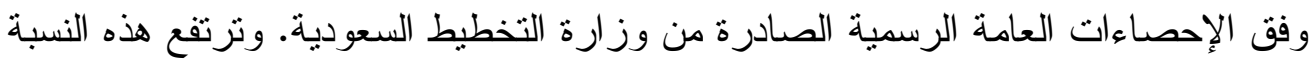

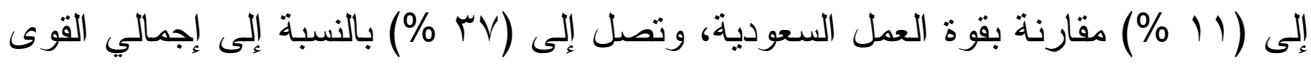
العاملة النسائية من سعوديات وو افدات.

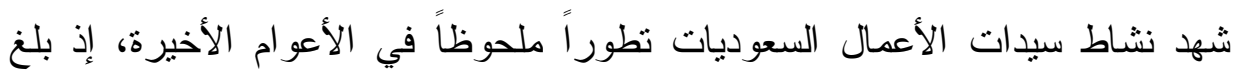

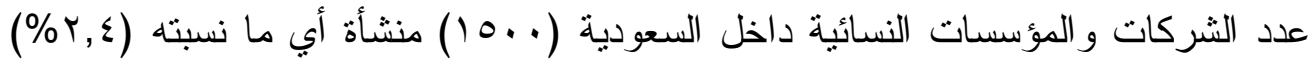

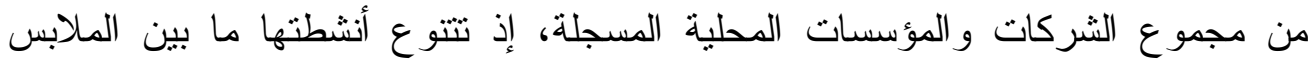

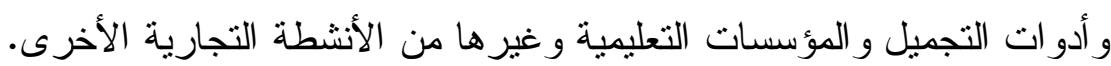

ومن بين (سTr I ) ترخيصاً أصدرتها هيئة المشروعات النسائية الدولية حتى نهاية

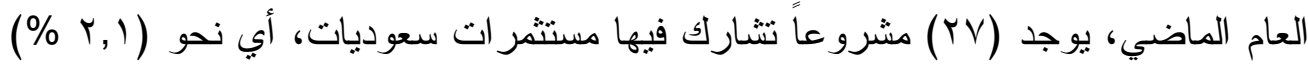

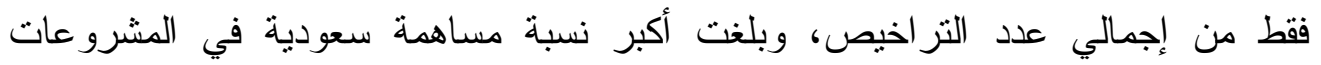

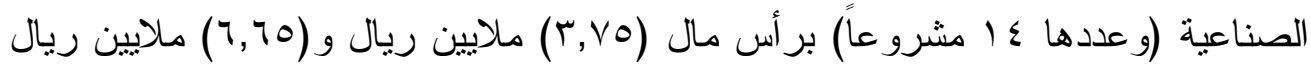
للمشروعات الخدمية البالغ عددها (T ا ( ) مشروعاً. 


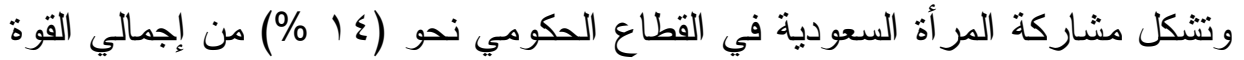

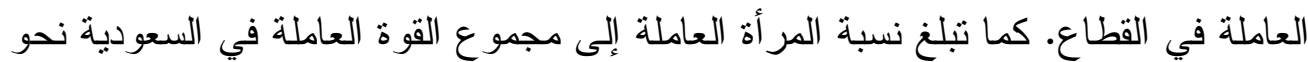

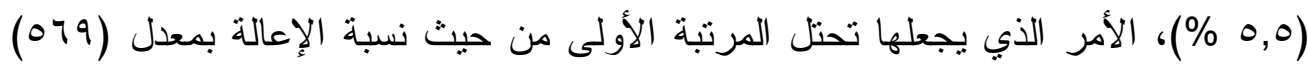

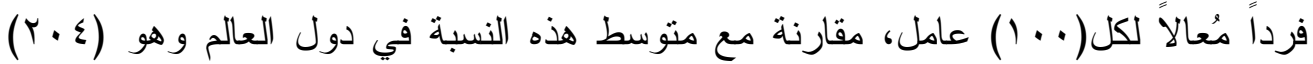

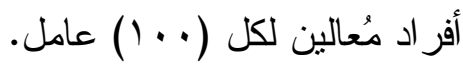

وقد أثنارت الدراسات السابقة أن و اقع تمكين المرأة السعودية في المناحي الاقتصادية غير التعليمية يتمنل بالنقاط الآتية: ا. تمثلك المر أة المستثرة الاستقلالبة و القدرة على اتخاذ القرار باستثناء القدرة على إنهـاء الإجر اءات الخاصة بها في الدو ائر الحكومية و الخاصة.

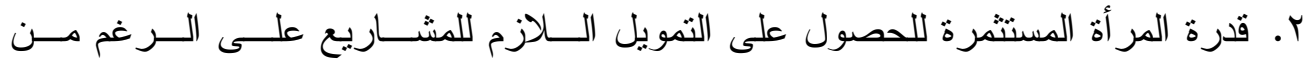
الإجر اءات اللازمة للحصول على قروض معقد وطويلة.

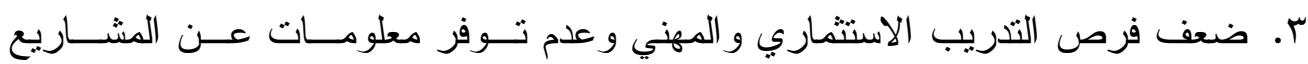

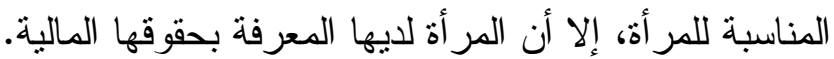


تشارك في رسم السياسات الحكومية الخاصة بها.

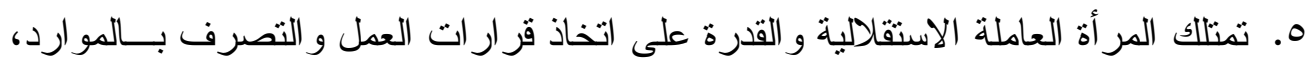
لكنها لا تستطيع شخصياً إنهاء الإجر اءات الخاصة بها في الدو ائر الحكومية و الخاصة.

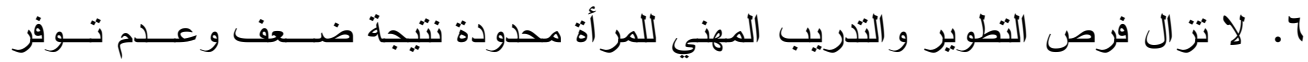
البر امج التدريبية سواء المهنية أو الاستثمارية.

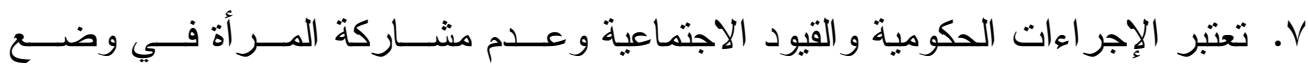

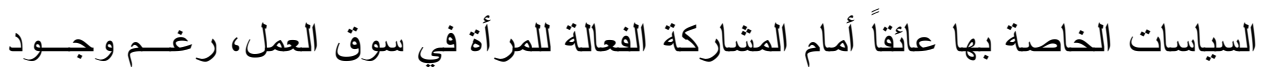

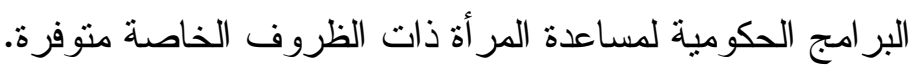

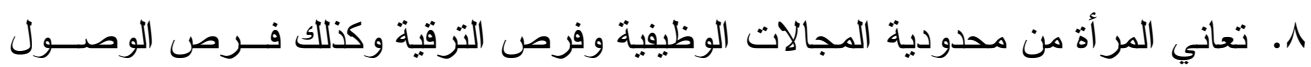

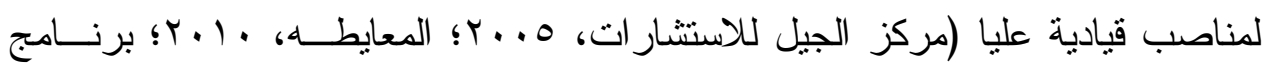

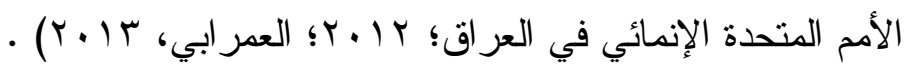




\section{نتائج الدر اسة}

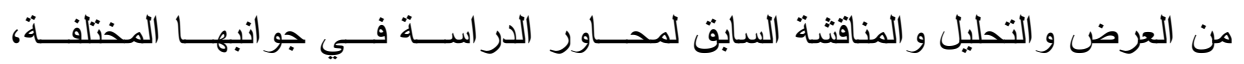
وبالاطلاع على نتائج الدر اسات السابقة، وبالاطلاع على مضدون الجداول و الإحصــائيات

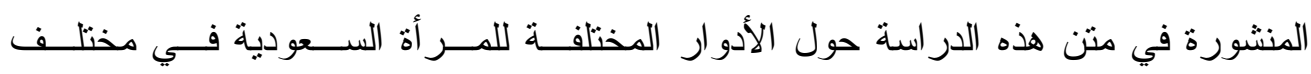
القطاعات، يمكن تلخيص أهم النتائج التي نم التوصل إليها بالنقاط الآتية: ا ـ أن معدلات القيد للبنات في التعليم العالي فاقت نظريتها لتعليم البنين. r. التخصصات الموجودة و المتاحة للمر أة محدودة وغير كافية رغم تتو عها وتحتاج إلى فتح المزيد من التخصصات التي تزيد من تقدم المر أة السعودية وتخدم سوق العمل وتحقق خطط التتمية، كما تم حرمانها من الدراسة الجامعية في مجالات العمارة

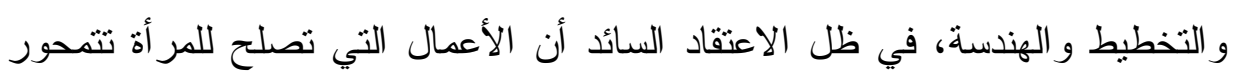

$$
\text { في التذريس و التمريض و الطب. }
$$

r. من الملاحظ أن الأعداد الهائلة من الخريجات من المراحل الثانوية ومعاهد ما بعد الثانوية لا تلتحق بسوق العمل. و لا توجد إحصائية دقيقة لتحديد تكلفة هذه الخسارة، سو اء من ناحية النفقات التعليمية أو تكاليف الفرص. ع. يغلب على مخرجات التعليم العالي التخصصات النظرية و التزبوية مع تدني مستوى الكفاءة؛ إذ إن المخرجات التعليمية لا تسير متوازية مع احتياجات السوق؛ لأن التدريب العملي لم يؤخذ في الاعتبار في المناهج. وينطبق هذا بصورة منساوية على كل من الرجال و النساء. م 0.تركز فرص العمل في تخصصات محددة. 7.تز ايد عدد الخريجات في التخصصات التربوية. V.تدني قدرة قطاع التعليم على استيعاب الكم الهائل من الخريجات. ^ـ انخفاض مشاركة المرأة في قوة العمل في القطاع الخاص. 
9 ـ تندي مشاركة المر أة في النشاط الاستثماري. • ا ـ وجود معوقات مؤسسية في مشاركة المر أة في النشاط التجاري. ا ا. ارتفاع نسبة من لا يجدن عملاً في الوظائف الحكومية. rا ـ من الملحوظ بصورة واسعة أن النظام النعليمي يعتبر نظرياً بشكل عام. و المشكلة

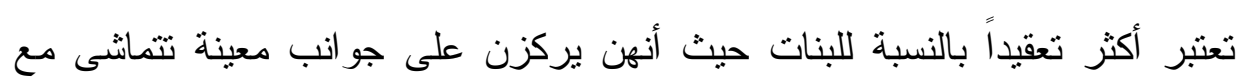
القسم الأدبي الذي لا يتيح لهن الفرصة لاخول الكليات العلمية و النطبيقية. rا ـ يعثقد بشكل عام أن الدراسات النظرية تقود إلى وظائف اجتماعية مقبولة مثل التدريس. ونادراً ما يتوجه البنات إلى التعليم التكنولوجي باستثناء المجال الطبي. و إذا لها نوقثت هذه المشكلة على نطاق عام، فمن المرجح أن تتنج عن حلول إبداعية في إطار الدين الإسلامي و المبادئ الاجتماعية. ع ا ـ لا تزال فرص النطوير و التدريب المهني للمرأة محدودية وضعيفة نتيجة ضعف توفر البر امج التنريبية سواء المهنية أو الاستثمارية، إضافة إلى عدم نوفر المعلومات عن المشاريع المناسبة للمرأة. وتتفق نتائج هذه الدراسة وما نوصلت إليه العديد من

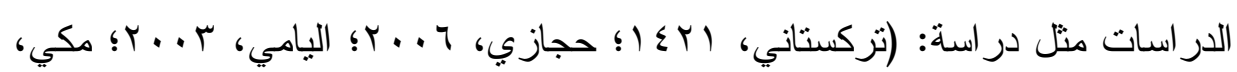

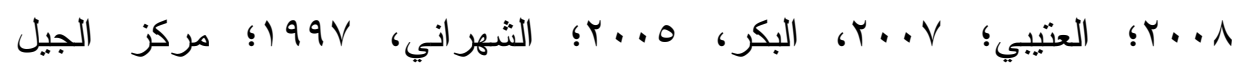

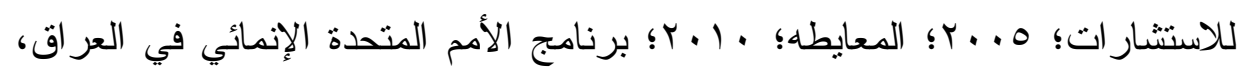

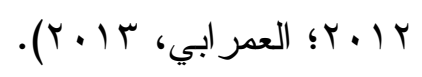


اقترحت الدر اسة عددًا من مداخل الحلول لزيادة معدلات توظيف المر أة السعودية في القطاعين العام و الخاص. وتتمحور تلك التوصيات في: ا. تطبيق الحقوق التي أقرتها الثريعة للمرأة والتي منها التعليم إلى اللحد، وهذا من أهم الحقوق لما له من أهمية في إز الة أكبر العوائق و السلبيات التي تصيب المجتمعات من ون

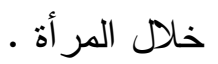
r. ضرورة بث الوعي العام بأن الشريعة شملت الرجال و النساء وأن النساء شقائق الرجال عن طريق وسائل الإعلام بإنشاء قناة علمية لنشر التوعية من أجل الاهتمام بالمر أة المسلمة وكيفية إعدادها الإعداد الذي يحفظ لها كيانها لأنها تلك المسلمة التي لته شملتها الثريعة و أعطتها حقوقها في التعليم وغيره منت الرجل لأن طلب العلم فريضة على كل مسلم ومسلمة. وعملاً بقوله تعالى: " ولهن مثل الذي عليهن

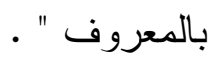
ץ. أهمية إعداد المرأة السعودية للمرحلة القادمة من خلال التركيز على التخصصات النطبيقية في الجامعات و الكليات. ع. التوسع في تعليم جميع التخصصات الطبية بما يخص المرأة منل: أثنعة -جراحة تخدير، وتخصيص المرأة في مجال الفيزياء الطبية و الكيمياء الحيوية السريرية و العلاج الطبيعي.

ه. السماح للمر أة بدراسة القانون و الثريعة معاً في تخصص المحاماة لتعمل المرأة محامية تستمع لبنات جنسها في قضاياهم الخاصة بدلا من اللجوء للمحامي الرجل وتقدم بعد ذلك للمحكمة مع ضرورة دراسة حكم عمل المرأة كمحامية من الناحية الثرعية T. فتح تخصصات جديدة للمرأة مثل: تخصص التعليم الخاص لذوي الاحتياجات

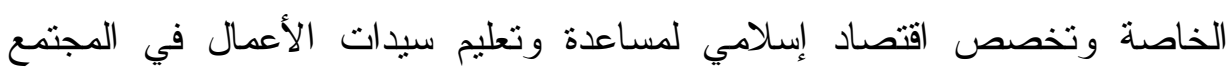


وتخصص الهنسة الاكترونية و الكهربائية والإدارة المالية و إدارة المستودعات وتخصص تصميم مجوهر ات وتصميم أزياء وتخصص الفنون التشكبلية. V. تكثيف بر امج التنريب التقني، و الفني، و المهني النسائي، و اتخاذ أسلوب إعادة التأهيل

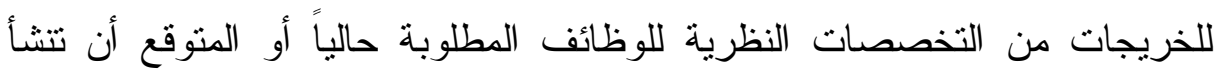
الحاجة لها مستقبلاً، خاصة في مجالات العلوم الطبية المساعدة، والتغذية، وتقنية الاتصالات و المعلومات عموماً وفي مجال الحكومة الإكترونية و التجارة الإلكترونية على وجه الخصوص، وذلك في ظل توجهات سوق العمل لهذين المجالين في الفترة القادمة، والأخذ في الاعتبار انضمام المملكة لمنظمة التجارة العالمية، وما سوف تحدثه تلك العضوية من تغير ات في أسلوب الإدارة و التعاملات التجارية المستقلية. ^. نوصي الدراسة بتأنيث جميع الوظائف المرتبطة مباشرة بشؤون المرأة، وتوفير

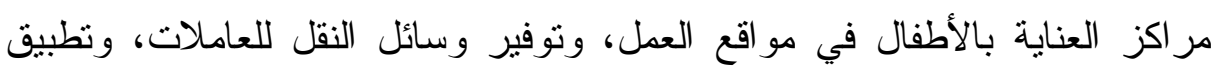
أسلوب العمل المرن و العمل الجزئي، و العمل عن بعد(كونه أسلوبا من شانه أن يسهم في حل مشكلة البطالة النسائية)، بوصفه من أبرز الأساليب التي طبقت في كثثر من الدول المتقدمة و النامية لحل مشكلة البطالة. 9. العمل على إيجاد فرص وظيفية تتلاعم مع المرأة في إطار الثريعة الإسلامية وتقاليد المملكة؛ لأن مشكلة بطالة الخريجات سوف تكون اكبر مشكلة تواجه التعليم العالي خلال العشرين السنة القادمة؛ إذا لم تكن هناك خطو ات عملية لإيجاد حلول لها.

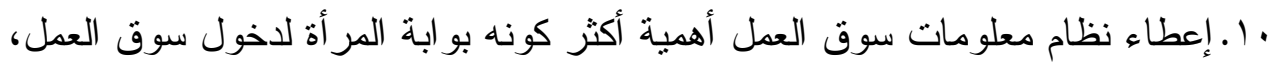
من خلال تطوير قاعدة المعلومات في مكاتب العمل الحكومية ومكاتب التوظيف الأهلية. الضرورة استخدام الوسائل الحديثة في نشر الوظائف المتاحة للمر أة كالانترنت، كونها من الوسائل المفضلة لدى النساء، إضافة إلى الصحف و المجلات المتخصصة. rا إعادة هيكلة سوق العمل بحيث يمكن تحقيق التوازن بين الجنسين. يجب أن يفهم أن سوق العمل المتوازن بين الجنسين سوف يساعد المملكة على تحقيق أهداف التتمية للألفية الثالثة قبل حلول عام (10 • ب)، وتحقيق تتمية بشرية مستدامة. 
rا..دراسة تأسيس مجموعة من الصناعات المنزابطة للمحترفات من النساء، ونوفير التدريب للنساء في القطاعات المستهدفة (وخاصة قطاع الخدمات و الصناعات الدو ائبة).

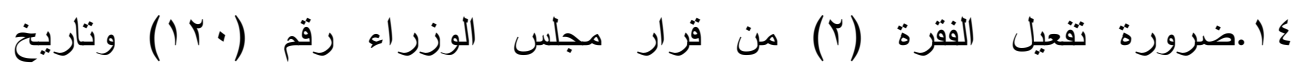

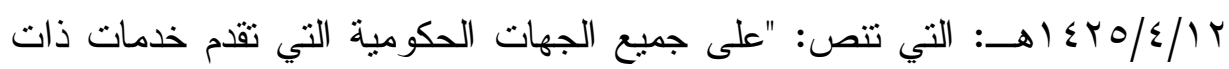
علاقة بالمر أة إنشاء وحدات وأقسام نسائية - بحسب ما تقتضيه حاجة العمل فيها وطبيعته- خلال مدة لا تزيد عن سنة من تاريخ صدور هذا القرار". على أن ير اعى ولى

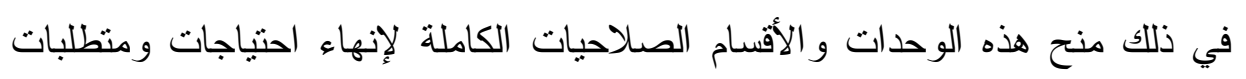
النساء، وليس الأمر مجرداً عن جعلها حلقة وصل بين النساء و الأقسام الرجالية. 1 اضرورة زيادة مشاركة مساهمة المرأة في رسم السياسات في المسائل المتعلقة بشؤونها. ويكون ذللك من خلال الإسراع في تفعيل الفقرة (0) من قرار المجلس

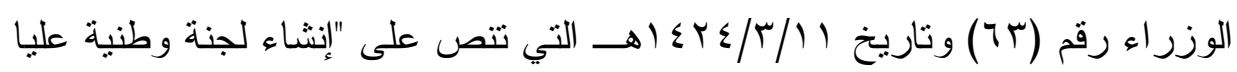

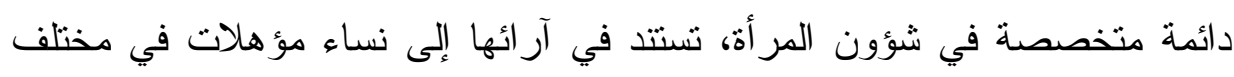

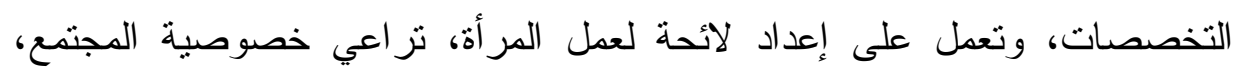
وتؤكد على حق المر أة في الوظيفة و العيش الكريم. 


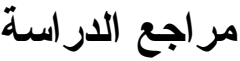

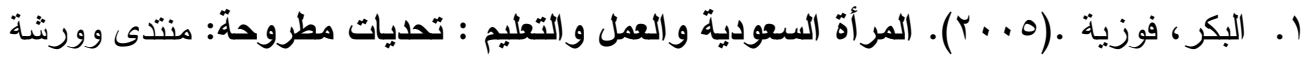
عمل" المرأة والألفية "برنامج الأمم المتحدة الإنمائي في الفترة 17-15 ذو القعدة1426 هـ) الموافق 19 - 17 ديسمبر 2005 م (مقر الأمم المتحدة

$$
\text { بالرياض). }
$$

r. الحسيني، عائشة.(Y991 (19). " تقييم مساهمات المرأة السعودية في سوق العمل "، طا، جامعة

$$
\text { الملك عبد العزيز، مركز النشر العلمي. }
$$

r. الخطيب، محدد شحات. (ع . . ب). المرأة حقوقها وواجباتها وعلاقة التعليم بذلك. جامعة

$$
\text { الملك سعود. }
$$

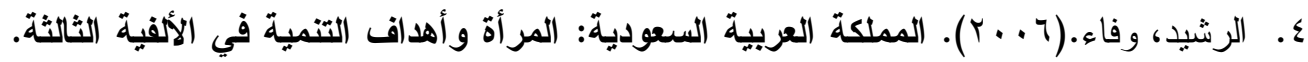
برنامج الأمم المتحدة للتمية، الرياض، المملكة العربية السعودية. ه. الشهراني، مريم. (997 (1)." مدى إسهام المرأة السعودية المؤهلة في الوظائف المتاحة وإمكاتية زيادة الفرص الوظيفية المناسبة لها في القطاعين العام والخاص"، رسالة ماجستير ، جامعة أم القرى، كلية التزبية، مكة المكرمة. ؟. الصبان، مريم سرور .(1991). : التعليم العالي وعلاقته بسوق عمل المرأة في مدينة مكة المكرمة نموذجاً عن المملكة العربية السعودية ، دراسة مقدمة إلى ندوة

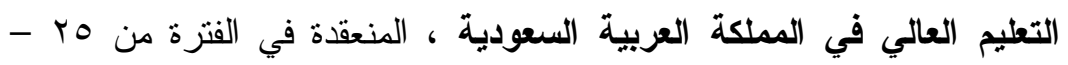

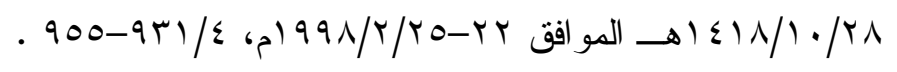

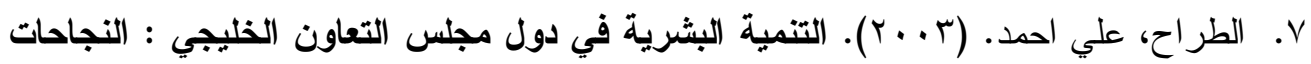

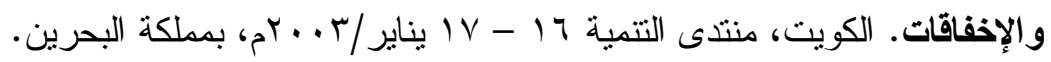

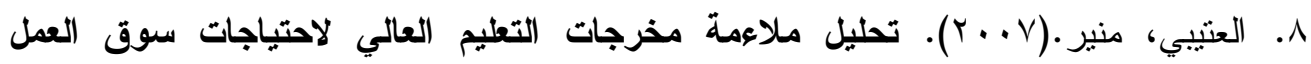
السعودي. قســم التربية - كلية النزبية. جامعة الملك سعود. 9 9. العمر ابي،السر .(r • ب). تمكين المرأة في سلطنة عمان. مؤسسة الانتشار العربي، سلطنة 
• ا. الفارس، عبد الرزاق فارس (991)). مشروع استثراف مستقبل العمل التربوي في دول الخليج العربية: دراسة مؤشرات النمو الكمية التربوية في ضوء الإسقاطات السكاتية والاقتصادية خلا العقدين القادمين في الدول الأعضاء، الرياض:

$$
\text { مكتب التربية العربي لدول الخليج. }
$$

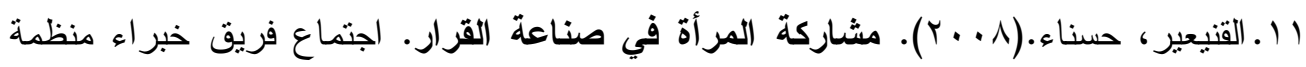

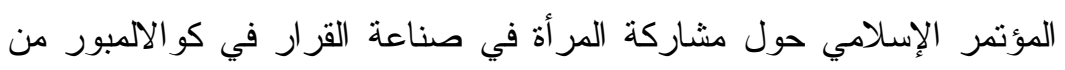

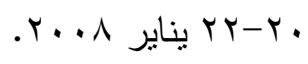

r ا. المعايطه، رويده. (• (ץ). النوع الاجتماعي وأبعاد تمكين المرأة في الوطن العربي. منظمة

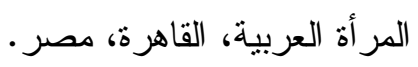

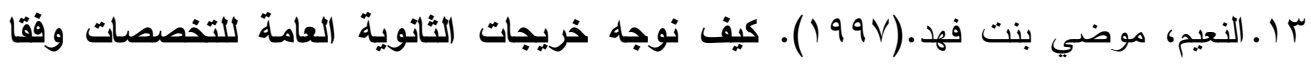
لاحتياجات سوق العمل السعودي. عالم الاقتصاد.

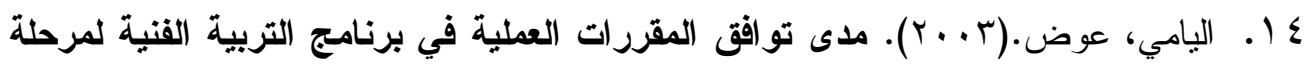



الملك سعود. جامعة الملك سعود، الرياض، المملكة العربية السعودية.

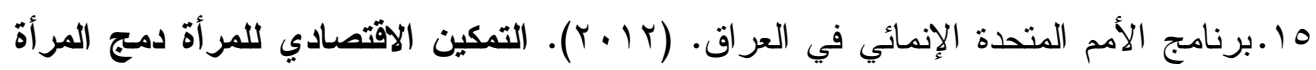
في الاقتصاد العراقي.

17 ا.تركستاني، معتبر .(1) (1). مدى تجاوب برامج التعليم الفني والمهني للبنات في توفير فرص وظيفة جديدة للفتاة السعودية. المملكة العربية السعودية. V ا . جمعية النساء العربيات (1 . . r). وثثقة بعنوان" نقص تمكين المرأة" عمان، الأردن.

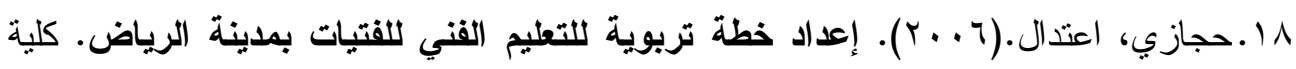
التربية للبنات بالإحساء.

9 ا.قرعان، هداية. (T . . r) التمكين والمرأة الفلسطينية. مركز الدراسات - أمان - المركز العربي للمصادر و المعلومات حول العنف ضد المرأة متاحة على الثبكة من من منرن

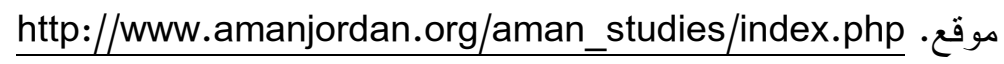




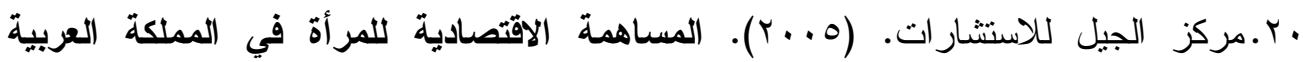

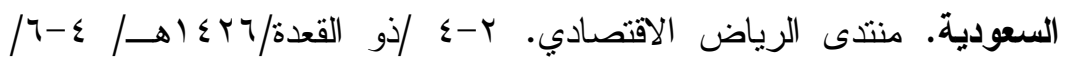

$$
\text { ديسمبر /0. }
$$

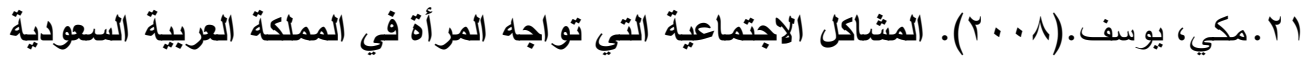

$$
\text { (المخارج و الحلول). المملكة العربية السعودية. }
$$

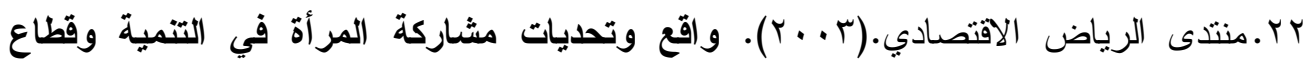

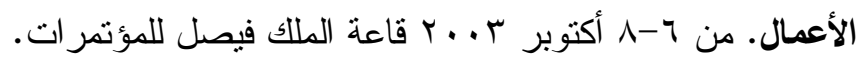

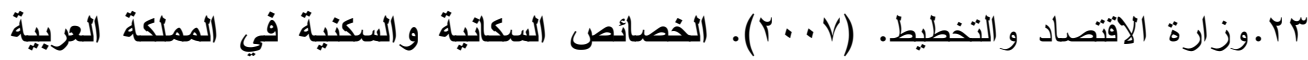
السعودية. مصلحة الإحصاءات العامة و المعلومات.

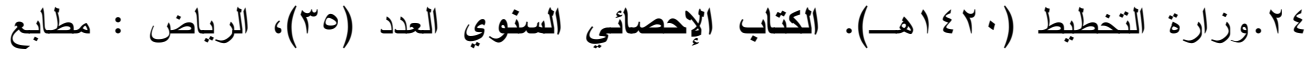
وزارة الاقتصاد و التخطيط.

هץ.وزارة التخطيط. (T ..ץ). مصلحة الإحصاءات العامة، الإحصاءات الاجتماعية " نشرة

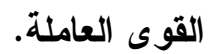

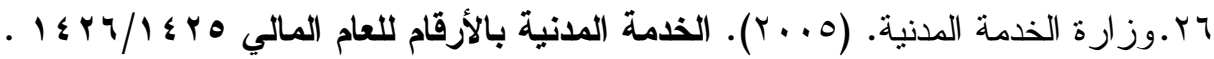
27. UNESCO (1997) .Declaration and Action Plan on Higher Education in Africa', African Regional Consultation Preparatory to the World Conference on Higher Education, Dakar, 1-4 April.

28. UNESCO (1997) .Declaration about Higher Education in Asia and the Pacific'. Regional Conference on Higher Education: National Strategies and Regional Co-operation for the 21st Century. Tokyo, July 8-10.

29. UNESCO (1998). Consolidated Declarations and Plans of Action of the Regional Conferences on Higher Education held in Havana, Dakar, Tokyo, Palermo and Beirut. Retained Lessons. UNESCO, Paris 